\title{
Recovery of Magnesium from Ferronickel Slag to Prepare Magnesium Oxide by Sulfuric Acid Leaching
}

\author{
Juan Yang ${ }^{1,2, \dagger}$, Xuqin Duan ${ }^{1,2, *}$, Lingchuan Liu ${ }^{1,2, \dagger}$, Huifen Yang ${ }^{1,2}$ and Xiaocui Jiang ${ }^{1,2}$ \\ 1 School of Civil and Resource Engineering, University of Science \& Technology Beijing, Beijing 100083, China; \\ g20198115@xs.ustb.edu.cn (J.Y.); g20198060@xs.ustb.edu.cn (L.L.); yanghf@ustb.edu.cn (H.Y.); \\ jxc18410202983@163.com (X.J.) \\ 2 State Key Laboratory for Efficient Mining of Metal Mines, University of Science \& Technology Beijing, \\ Beijing 100083, China \\ * Correspondence: dxq918@ustb.edu.cn \\ + Juan Yang and Lingchuan Liu contribute equally to this work.
}

Citation: Yang, J.; Duan, X.; Liu, L.; Yang, H.; Jiang, X. Recovery of Magnesium from Ferronickel Slag to Prepare Magnesium Oxide by Sulfuric Acid Leaching. Minerals 2021, 11, 1375. https://doi.org/10.3390/ $\min 11121375$

Academic Editors: Ilhwan Park and Marthias Silwamba

Received: 5 November 2021

Accepted: 3 December 2021

Published: 6 December 2021

Publisher's Note: MDPI stays neutral with regard to jurisdictional claims in published maps and institutional affiliations.

Copyright: (c) 2021 by the authors. Licensee MDPI, Basel, Switzerland. This article is an open access article distributed under the terms and conditions of the Creative Commons Attribution (CC BY) license (https:/ / creativecommons.org/licenses/by/ $4.0 /)$.

\begin{abstract}
This paper provides a technical approach for efficiently recovering $\mathrm{Mg}$ from ferronickel slag to produce high-quality magnesium oxide $(\mathrm{MgO})$ by using the sulfuric acid leaching method under atmospheric pressure. The leaching rate of magnesium is $84.97 \%$ after a typical one-step acid leaching process, which is because $\mathrm{Mg}$ in FNS mainly exists in the forsterite $\left(\mathrm{Mg}_{2} \mathrm{SiO}_{4}\right)$ phase, which is chemically stable. In order to increase the leaching rate, a two-step acid leaching process was proposed in this work, and the overall leaching rate reached up to $95.82 \%$ under optimized conditions. The response surface methodology analysis for parameter optimization and $\mathrm{Mg}$ leaching rules revealed that temperature was the most critical factor affecting the $\mathrm{Mg}$ leaching rate when the sulfuric acid concentration was higher than $2 \mathrm{~mol} / \mathrm{L}$, followed by acid leaching time. Furthermore, interactive behavior also existed between the leaching temperature and leaching time. The leaching kinetics of magnesium from FNS followed a shrinkage-nuclear-reaction model with composite control, which were chemically controlled at lower temperatures and diffusion controlled at higher temperatures; the corresponding apparent activation energy was $19.57 \mathrm{~kJ} / \mathrm{mol}$. The leachate can be used to obtain spherical-like alkali magnesium carbonate particles with diameters of 5-10 $\mu \mathrm{m}$ at $97.62 \%$ purity. By using a further calcination process, the basic magnesium carbonate can be converted into a light magnesium oxide powder with a particle size of $2-5 \mu \mathrm{m}$ (MgO content $94.85 \%)$, which can fulfill first-level quality standards for industrial magnesium oxide in China.
\end{abstract}

Keywords: ferronickel slag; sulfuric acid leaching; light magnesium oxide

\section{Introduction}

Ferronickel slag (FNS) is considered as the main solid wastes discharged from hightemperature smelting of laterite ores during the ferronickel production process. An approximate estimation shows that 12-14 tons of FNS can be generated within the production process of 1 ton of nickel alloy [1,2]. The output of ferronickel slag has increased to approximately $40 \mathrm{Mt}$ in 2020, ranking as the fourth largest industrial solid waste in China, followed by iron slag, steel slag, and red mud [3]. However, at the present stage, less than $10 \%$ of FNS has been utilized [4], and most FNS was disposed of in an open environment, which not only poses a great potential threat to the environment and human health due to its hazardous components (e.g., chromium) but also results in a large waste of its contending resources. Thus, clean and highly efficient utilization of FNS represents a meaningful and interesting research area, especially given the global awareness of carbon reduction.

Over the past few decades, efforts have been made in the utilization of ferronickel slag. Most have focused on applying ferronickel slag for making construction and building materials (e.g., cement, concrete, and geopolymers) because of the high contents of amorphous $\mathrm{SiO}_{2}[5-9]$, producing glass ceramics $[10,11]$ and mineral wool [12] due to the glass and 
microcrystalline structure, and preparing forsterite refractory materials based on its higher $\mathrm{MgO}$ content [13-16]. However, these application pathways have some shortcomings, such as complex processes, large initial investment, and low product quality, resulting in low efficiency of FNS utilization. FNS contains appreciable amounts of base metals and is also considered to be an important secondary source of valuable metals. Most relevant studies have focused on the extraction of iron, nickel, cobalt, and chromium in the past [17-19]. The main methods include high-temperature roasting [20], atmospheric or oxygen pressure leaching with acid [21-24], and microbial leaching [25,26].

In the last decade, with the gradual exhaustion of natural magnesium-rich mineral resources, efficient utilization of magnesium in FNS has received more attention. Many methods for recovering magnesium from ferronickel slag have been reported, e.g., vacuum reduction [27], ammonium sulfate roasting [28], sodium hydroxide $(\mathrm{NaOH})$ [29], hydrochloric acid $(\mathrm{HCl})$ [30], and sulfuric acid $\left(\mathrm{H}_{2} \mathrm{SO}_{4}\right)$ [31] leaching. Although vacuum reduction has a higher leaching rate $(97.74 \%)$, operation at elevated temperatures $(1573 \mathrm{~K})$ is not attractive for processing secondary resources. Compared with the vacuum reduction method, the ammonium sulfate roasting method is more competitive due to its lower roasting temperature of $300 \sim 600{ }^{\circ} \mathrm{C}$, and without consuming acid and alkali. However, only $90 \%$ of magnesium could leach from FNS into water under the optimum conditions [28]. The leaching rate of magnesium from FNS was 73.10\% with sodium hydroxide, which was not satisfactory [29]. Due to its simple process, low investment cost, and relatively low environmental pollution, the atmospheric pressure acid leaching process is a potential direction for industrial applications. Since silicate minerals are relatively difficult to dissolve in $\mathrm{HCl}$ in comparison to oxides and hydroxides [30], sulfuric acid is the preferred choice. According to Gao's study [31], 87.46\% of $\mathrm{Mg}$ was removed into the leach liquor through a two-stage sulfuric acid leaching process. Gao's leaching results are not ideal and the operation conditions are relatively tough. FNS sulfuric acid leachate is the mother liquor of magnesium products, which is similar to industrial magnesium sulfate solution. However, studies have already proved that iron, aluminum, and other metals will be synchronously leached during the sulfuric acid leaching of FNS [32], so the leachate contains not only a large amount of $\mathrm{Mg}^{2+}$, but also other metal ions, such as $\mathrm{Fe}^{2+}, \mathrm{Al}^{3+}, \mathrm{Cr}^{2+}$, etc. The negative effects of foreign metal ions on the magnesium product are inevitable. Producing high-purity magnesium products is a challenging task, which greatly depends on the purifying efficiency of $\mathrm{Mg}^{2+}$ in the leaching solution. Thus far, it is still urgent to efficiently recover magnesium from FNS to yield high purity magnesium products under mild technology conditions.

In this study, the leaching behavior of magnesium from FNS in sulfuric acid solution, purification of $\mathrm{Mg}^{2+}$, and preparation of high purity magnesium oxide are discussed. The appropriate factors for sulfuric acid leaching were determined by single-factor experiments. The response surface analysis was used to optimize the leaching process parameters and clarify the extent of each parameter influencing the leaching operation. The dissolution kinetics of magnesium from FNS were also investigated to provide theoretical guidance to elucidate the leaching process. This study proposed a feasible method for efficiently recovering $\mathrm{Mg}$ from ferronickel slag to prepare light magnesium oxide.

\section{Materials and Methods}

\subsection{Materials}

The FNS used in this study was obtained from a ferronickel smelting plant that operates with the rotary kiln-electric furnace (RKEF) process in Hebei Province, China. The main chemical composition of the FNS is shown in Table 1. It is characterized by a high $\mathrm{Mg}$ and Fe content and low $\mathrm{Al}$ and Ca content.

Table 1. Chemical composition of ferronickel slag (wt/\%).

\begin{tabular}{cccccccccccc}
\hline $\mathrm{SiO}_{2}$ & $\mathrm{MgO}$ & $\mathrm{Fe}_{2} \mathrm{O}_{3}$ & $\mathrm{CaO}$ & $\mathrm{Al}_{2} \mathrm{O}_{3}$ & $\mathrm{Cr}_{2} \mathrm{O}_{3}$ & $\mathbf{M n O}$ & $\mathrm{TiO}_{2}$ & $\mathrm{~K}_{2} \mathrm{O}$ & $\mathrm{Na}_{2} \mathrm{O}$ & $\mathrm{NiO}$ & Others \\
\hline 44.39 & 36.12 & 8.26 & 4.89 & 4.31 & 0.98 & 0.49 & 0.12 & 0.10 & 0.11 & 0.04 & 0.91 \\
\hline
\end{tabular}


X-ray powder diffraction (XRD) in combination with the Rietveld method was used to determine the phases in the FNS. The BGMN program was applied for Rietveld refinement [33]. Figure 1 shows the mineralogical compositions of the sample determined by Rietveld refinement. The $\mathrm{R}_{\mathrm{wp}}$ value was $7.88 \%$. Forsterite is the main component with a small amount of calcite and quartz with values of $1.41 \%$ and $0.08 \%$. In addition, the low background of the XRD pattern indicates that the ferronickel slag mineral has a large crystallinity, which makes the process of ore dissolution more difficult.

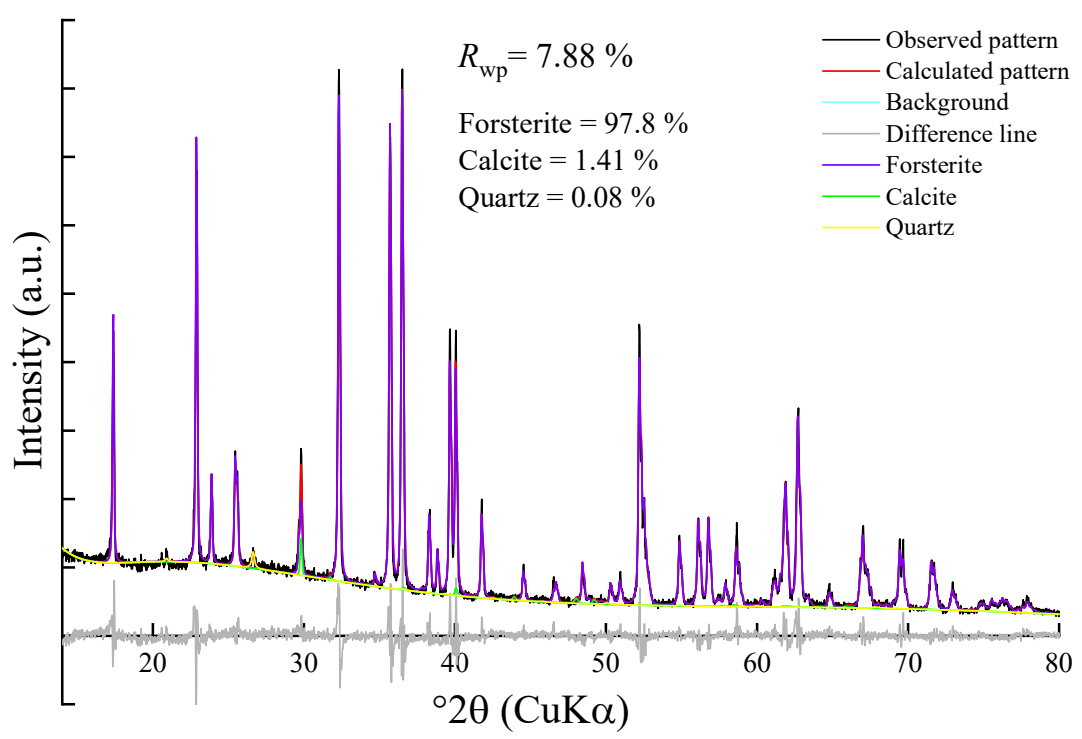

Figure 1. XRD pattern of ferronickel slag.

\subsection{Methods}

\subsubsection{Sulfuric Acid Leaching}

Ferronickel slag was first broken into fine particles with a size less than $2 \mathrm{~mm}$ by double teeth roll crusher then the uniformly mixed fine particles were ground through a sampling machine, and the collected powder was used as the raw sample used for the primary leaching experiment. In the leaching experiments, a specific concentration of sulfuric acid solution was poured into a conical flask, which was placed in a constant temperature water bath and heated to a specified temperature. Then, $20 \mathrm{~g}$ of FNS samples was soaked in sulfuric acid with a specific liquid-solid ratio (L/S) and magnetically stirred at a specified speed for a time while keeping the flask sealed. After the reaction was completed, the obtained mixture was carefully filtered with a vacuum filter, and the leaching residue was washed twice with hot sulfuric acid solution and thoroughly washed with deionized water until no $\mathrm{SO}_{4}{ }^{2-}$ was detected in the filtrate (tested by $\mathrm{BaCl}_{2}$ ). The filtrate was collected for the subsequent experiment, while the residue was dried at $100^{\circ} \mathrm{C}$ for $2 \mathrm{~h}$, and the mass of the dried residue was measured. According to the China industry standard-named determination of 22 metal elements in solid waste (HJ 781-2016), the dried residue was completely digested on the electric heating plate in the mixed acid solution, and the $\mathrm{Mg}$ content was measured by atomic absorption spectrophotometry to determine the leaching percentage, which was calculated using the following equations:

$$
\begin{aligned}
& \eta_{1}=\frac{\mathrm{m}_{0} \times \alpha_{0}-\mathrm{m}_{1} \times \alpha_{1}}{\mathrm{~m}_{0} \times \alpha_{0}} \times 100 \% \\
& \eta_{2}=\frac{\mathrm{m}_{1} \times \alpha_{1}-\mathrm{m}_{2} \times \alpha_{2}}{\mathrm{~m}_{1} \times \alpha_{1}} \times 100 \% \\
& \eta^{*}=\frac{\mathrm{m}_{0} \times \alpha_{0}-\mathrm{m}_{2} \times \alpha_{2}}{\mathrm{~m}_{0} \times \alpha_{0}} \times 100 \%
\end{aligned}
$$


where $\eta_{1}, \eta_{2}$, and $\eta^{*}$ are the $\mathrm{Mg}$ of primary, secondary, and comprehensive leaching percentage $(\%)$, respectively, $\mathrm{m}_{1}, \mathrm{~m}_{2}$, and $\mathrm{m}_{0}$ are the mass (g) of the first-stage leaching residue, second-stage leaching residue, and raw FNS, respectively, and $\alpha_{1}, \alpha_{2}$, and $\alpha_{0}$ are the mass percent (\%) of $\mathrm{Mg}$ in them, respectively.

The leaching residues with the highest $\mathrm{Mg}$ leaching ratio in primary and secondary leaching were analyzed by XRF and XRD, and the results were compared with the initial slag sample.

\subsubsection{Purification of Magnesium}

During the separation of $\mathrm{Mg}$ from impurities, $100 \mathrm{~mL}$ of acid leaching solution was first mixed with $1.5 \mathrm{~mL}$ of $15 \% \mathrm{H}_{2} \mathrm{O}_{2}$ in a $250 \mathrm{~mL}$ beaker, then the breaker was heated at $30{ }^{\circ} \mathrm{C}$ and simultaneously stirred at a speed of $200 \mathrm{rpm}$ for $10 \mathrm{~min}$ to convert $\mathrm{Fe}^{2+}$ into $\mathrm{Fe}^{3+}$. A sensitivity test was performed to assess whether $\mathrm{Fe}^{2+}$ was completely oxidized by using $0.1 \mathrm{~mol} / \mathrm{L}$ potassium ferricyanide. Then, the $\mathrm{pH}$ value of the solution was adjusted to $\mathrm{pH} 7$ using about $3 \mathrm{~mL}$ aqueous ammonia, so that the impurity ions such as $\mathrm{Fe}^{3+}, \mathrm{Al}^{3+}$, and $\mathrm{Cr}^{3+}$ in the leachate could be converted into hydroxide precipitation. Next, the $\mathrm{pH}$ of the solution was adjusted sequentially with aqueous ammonia in order to further remove the hybrids and obtain a purer magnesium sulfate solution and precipitate.

At the end of the purification process, the magnesium sulfate solution and precipitate were thoroughly separated by vacuum filtration. To evaluate the purifying efficiency, the magnesium filtrate was precipitated as hydroxide magnesium $\left(\mathrm{Mg}(\mathrm{OH})_{2}\right)$ by sodium hydroxide; the higher the $\mathrm{Mg}(\mathrm{OH})_{2}$ content, the higher the impurity removal rate and the better the impurity removal effect. At the same time, the $\mathrm{Mg}$ content of filter residue was analyzed by XRF to calculate the loss ratio of magnesium according to Equation (4):

$$
\eta_{\mathrm{L}}=\frac{\mathrm{m}^{\prime} \times \beta}{\mathrm{V} \times \mathrm{c}} \times 100 \%
$$

where $\eta_{\mathrm{L}}$ is the loss ratio of magnesium, $\mathrm{m}^{\prime}$ is the mass $(\mathrm{g})$ of filter residue after impurity removal, $\beta$ is the $\mathrm{Mg}$ content (\%) in it, and $\mathrm{V}$ and $\mathrm{c}$ are the solution volume (L) and its $\mathrm{Mg}$ content $(\mathrm{g} / \mathrm{L})$ before impurity removal, respectively.

\subsubsection{Preparation of Magnesium Oxide}

In this study, the alkaline magnesium carbonate calcination process was used to produce highly pure magnesium oxide. Firstly, the magnesium was precipitated into basic magnesium carbonate: $100 \mathrm{~mL}$ of purified magnesium sulfate solution was transferred into a $250 \mathrm{~mL}$ beaker, and a specified amount of ammonia water and ammonium bicarbonate were added. After stirring at a constant temperature for a certain period of time, a basic magnesium carbonate precipitation was obtained (the main reactions during the process are shown in Equation (5) [34]). After vacuum filtration, cleaning, and drying, basic magnesium carbonate powder was obtained. The magnesium precipitation effect is evaluated by the purity of $4 \mathrm{MgCO}_{3} \bullet \mathrm{Mg}(\mathrm{OH})_{2} \bullet 4 \mathrm{H}_{2} \mathrm{O}$ (Equation (6)) and the metal conversion rate (Equation (7)):

$$
\begin{gathered}
5 \mathrm{MgSO}_{4}+6 \mathrm{NH}_{3} \cdot \mathrm{H}_{2} \mathrm{O}+4 \mathrm{NH}_{4} \mathrm{HCO}_{3} \rightarrow 4 \mathrm{MgCO}_{3} \bullet \mathrm{Mg}(\mathrm{OH})_{2} \bullet 4 \mathrm{H}_{2} \mathrm{O}+5\left(\mathrm{NH}_{4}\right)_{2} \mathrm{SO}_{4} \\
\eta_{\mathrm{p}}=\frac{\gamma}{\gamma_{0}} \times 100 \% \\
\eta_{\mathrm{c}}=\left(\frac{\mathrm{m}-\mathrm{m}_{\mathrm{x}}}{\mathrm{m}}\right) \times 100 \%
\end{gathered}
$$

where $\eta_{\mathrm{p}}$ is the purity of $4 \mathrm{MgCO}_{3} \bullet \mathrm{Mg}(\mathrm{OH})_{2} \bullet 4 \mathrm{H}_{2} \mathrm{O}, \gamma$ is the content of $\mathrm{Mg}$ found in the obtained $4 \mathrm{MgCO}_{3} \bullet \mathrm{Mg}(\mathrm{OH})_{2} \bullet 4 \mathrm{H}_{2} \mathrm{O}, \gamma_{0}$ is the theoretical amount of $\mathrm{Mg}$ in $4 \mathrm{MgCO}_{3} \bullet \mathrm{Mg}(\mathrm{OH})_{2}$ - $4 \mathrm{H}_{2} \mathrm{O}, \eta_{\mathrm{c}}$ is the conversion percentage of metals, and $\mathrm{m}_{\mathrm{x}}$ and $\mathrm{m}$ are the total amount of metals after precipitation and in the original solution, respectively. 
Secondly, the obtained basic magnesium carbonate was placed in a muffle furnace at a rate of $10{ }^{\circ} \mathrm{C} / \mathrm{min}$ and heated to $900{ }^{\circ} \mathrm{C}$ and then calcined at a constant temperature for $90 \mathrm{~min}$ (the main chemical reaction of calcination is shown in Equation (8)). Then, the furnace was cooled to room temperature, and the obtained powder was light magnesium oxide. Figure 2 shows the process flow diagram of recovering $\mathrm{Mg}$ from FNS to prepare $\mathrm{MgO}$.

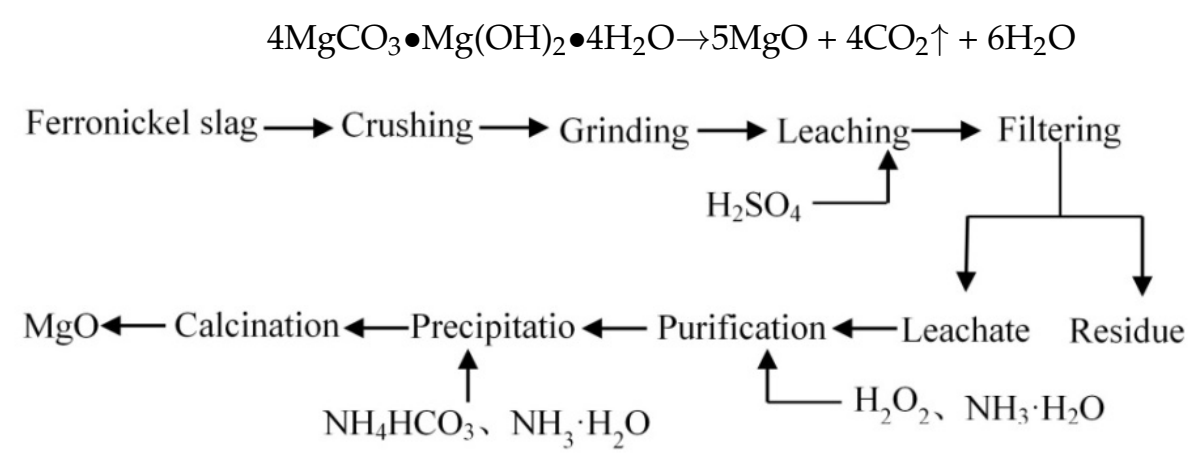

Figure 2. Process flow of recovering $\mathrm{Mg}$ from FNS to prepare $\mathrm{MgO}$.

\subsection{Characterization Methods}

The Mg content in all leaching residues was determined by atomic absorption spectrophotometry (Z-2000, Tokyo, Japan) under the following instrument operating conditions: acetylene flow of $3.0 \mathrm{~L} / \mathrm{min}$, lamp current of $4 \mathrm{~mA}$, slit width of $1.0 \mathrm{~nm}$. The chemical compositions of ferronickel slag and leaching residues were examined using an X-ray fluorescence spectrometer (Kyoto, Japan, XRF-1800), which operated at $60 \mathrm{kV}$ voltage and $140 \mathrm{~mA}$ current with a scanning speed of $300^{\circ} / \mathrm{min}$. The phase composition of the samples was determined by the Rietveld method using X-ray diffraction (XRD) data. The measurements were performed on a Rigaku Ultima IV instrument (Kyoto, Japan, at $40 \mathrm{~mA}$ and $40 \mathrm{kV}$ ) using $\mathrm{CuK} \alpha$ radiation with a wavelength of $1.5406 \AA$ in $10^{\circ}$ to $80^{\circ} 2 \theta$ range with an angular speed of $20^{\circ} / \mathrm{min}$. The BGMN program was applied for Rietveld refinement. The morphology of the samples was characterized by a scanning electron microscope (SEM, MV-RR-CNJ-0010, Shanghai, China) equipped with an energy dispersive spectroscopy (EDS) detector. All chemicals used in the study were from the laboratory of the University of Science and Technology, Beijing, and were analytical grade. Deionized water was used throughout the experiments and analytical measurements.

\section{Results and Discussion}

\subsection{The Acid Leaching Process of Ferronickel Slag}

The effects of FNS grinding fineness, acid concentration, liquid-to-solid ratio, leaching temperature, leaching time, and stirring speed on the magnesium leaching percentage were studied, and the results are shown in Figure 3.

Figure $3 a$ indicates that the leaching efficiency of magnesium increased gradually with decreasing particle size. This is attributed to the increase in the specific surface areas of the samples, which provides a greater reaction interface between the sulfuric acid and FNS particles. However, a smaller particle size does not necessarily lead to a higher extraction rate and may even have a negative influence [35]. Therefore, the optimum grinding fineness was determined to be -0.074 , $\mathrm{mm}$ accounting for $94.5 \%$.

Figure $3 \mathrm{~b}$ shows that a modest increase in acid concentration was beneficial to increase the $\mathrm{Mg}$ leaching rate. Around $63.90 \%$ of magnesium can be extracted when the concentration of acid reaches $2.8 \mathrm{~mol} / \mathrm{L}$, and the reasons for the decrease at a higher concentration were because (1) the viscosity of the slurry increased, (2) the mass transfer efficiency was reduced, and (3) the soluble sulfuric magnesium was captured in the residue. A previous study also concluded that an appropriate sulfuric acid concentration was identified to ensure a reasonable final $\mathrm{pH}$ level to inhibit the generation of colloidal silica and produce 
acceptable solid-liquid separation characteristics of the leaching slurry [18]. Hence, a lower sulfuric acid concentration is practically acceptable.

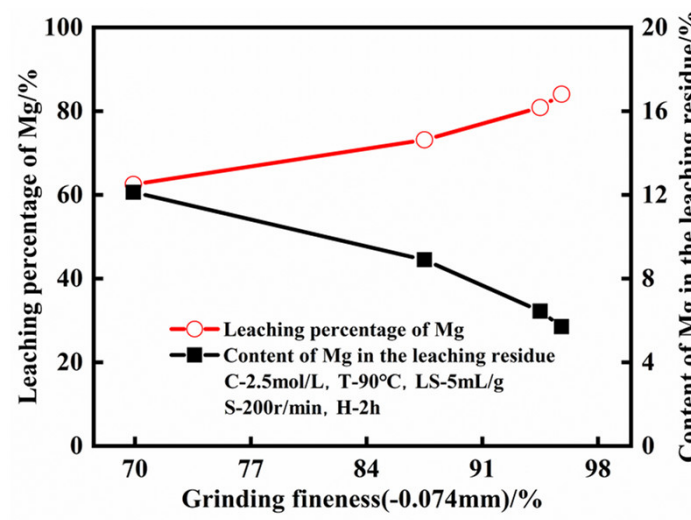

(a)

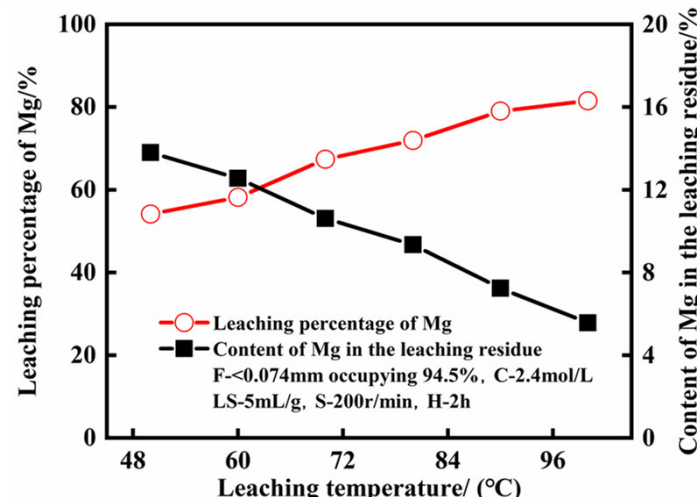

(c)

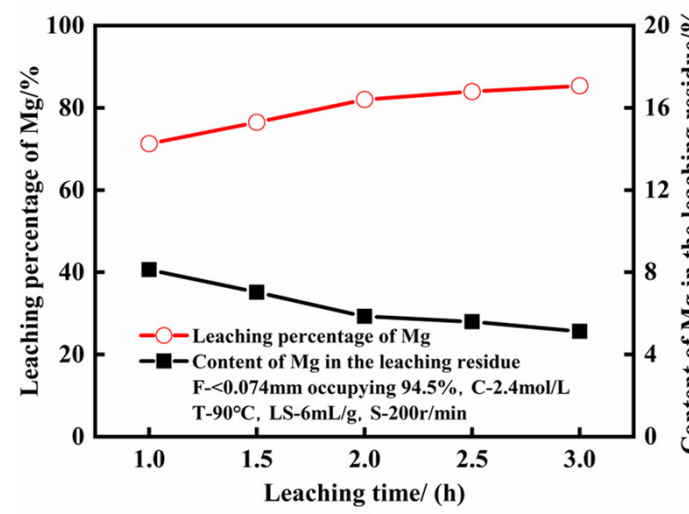

(e)

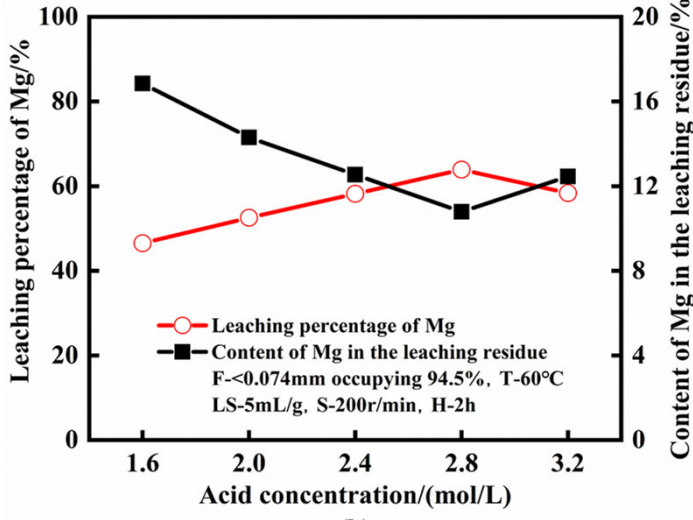

(b)

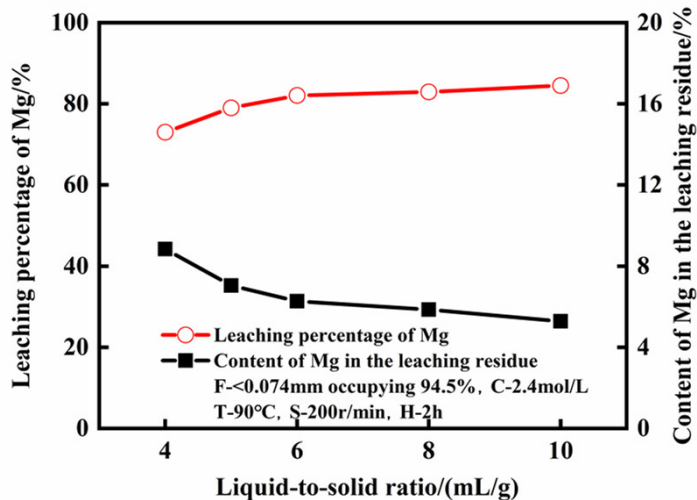

(d)

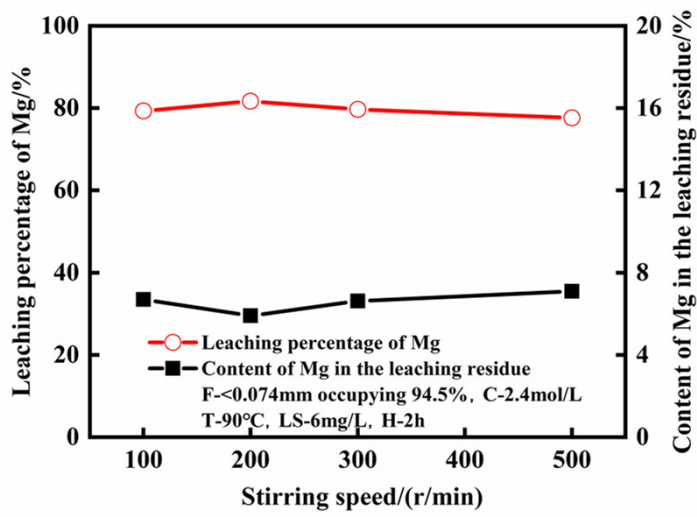

(f)

Figure 3. Effect of variables on the efficiency of leaching magnesium from ferronickel slag (a) grinding fineness; (b) acid concentration; (c) leaching temperature; (d) liquid-to-solid ration; (e) leaching time; (f) stirring speed (F-grinding fineness; $\mathrm{C}$-acid concentration; T-leaching temperature; LS-liquid-to-solid ratio; H-leaching time; S-stirring speed).

The results of Figure 3c show that the extraction rate of magnesium increased by $27.39 \%$ when the temperature increased from $50{ }^{\circ} \mathrm{C}$ to $100{ }^{\circ} \mathrm{C}$. Correspondingly, the content of $\mathrm{Mg}$ in the leaching residue decreased from $12.55 \%$ to $5.56 \%$, which indicates that the leaching rate of magnesium is highly dependent on temperature. An increase in temperature will increase the available energy in the reaction system and accelerate the thermal movement of $\mathrm{H}^{+}$and crystal lattice molecules of forsterite. With a faster diffusion rate, the effective number of collisions between $\mathrm{H}^{+}$and FNS particles increases, which makes it easier for $\mathrm{H}^{+}$ions to abolish the crystal lattice of forsterite, and thus, enhances the $\mathrm{Mg}^{2+}$ leaching rate. A higher leaching temperature is advantageous for the increase in $\mathrm{Mg}$ leaching velocity and leaching ratio. However, $\mathrm{H}_{2} \mathrm{SiO}_{3}$ may be formed when leaching at 
a temperature above $99{ }^{\circ} \mathrm{C}$, which is harmful to the leaching of $\mathrm{Mg}$, because $\mathrm{H}_{2} \mathrm{SiO}_{3}$ can increase the solution viscosity by forming a colloidal substance. $\mathrm{SiO}_{2}$ may be the stable form of $\mathrm{Si}$ when the leaching occurs at a temperature lower than $99{ }^{\circ} \mathrm{C}$, which is less harmful [31]. Therefore, the sulfuric acid leaching temperature of FNS should be controlled lower than $99{ }^{\circ} \mathrm{C}$.

Figure $3 \mathrm{~d}$ illustrates that increasing the liquid-to-solid ratio is beneficial to the extraction of magnesium. As the liquid-to-solid ratio increases, the slurry density gradually decreases, accelerating mass transfer, and therefore, providing benefits to mineral dissolution. Moreover, as the solution viscosity decreases, FNS particles can more efficiently contact sulfuric acid. However, it was noteworthy that a relatively low degree of extraction improvement occurred when the liquid-to-solid ratio exceeded $6 \mathrm{~mL} / \mathrm{g}$.

Figure $3 e$ shows the tendency of magnesium extraction when the leaching time gradually increases from $60 \mathrm{~min}$ to $180 \mathrm{~min}$. Moreover, it was observed that magnesium extractions increased significantly with the increase in leaching time until $120 \mathrm{~min}$, and then gradually reached a stable state. This can be attributed to the fact that only a small amount of unreacted FNS particles remained after leaching for $120 \mathrm{~min}$, and the probability of intermolecular collisions decreased with the consumption of sulfuric acid. In addition, amorphous silica was produced simultaneously, which was easy to accumulate on the surface of the reactor and hinder the reaction.

As shown in Figure $3 \mathrm{f}$, the stirring speed has an indistinctive effect on the leaching rate. The stirring should ensure that the particles are effectively suspended, but cannot be too fast; this is because excessive mixing speed causes the material in the leaching system to rotate, which makes it easy to agglomerate on the stirring bar, resulting in a poor mass transfer effect and slow leaching rate.

Considering the leaching efficiency, filterability of leaching slurry, and energy consumption, the proper technical conditions for primary leaching were determined as follows: raw material grinding fineness of $-0.074 \mathrm{~mm}$ occupied $94.5 \%$, acid concentration of $2.4 \mathrm{~mol} / \mathrm{L}$, leaching temperature of $90{ }^{\circ} \mathrm{C}$, liquid-to-solid ratio of $6 \mathrm{~mL} / \mathrm{g}$, leaching time of $120 \mathrm{~min}$, stirring speed of $200 \mathrm{r} / \mathrm{min}$, and leaching percentage of $\mathrm{Mg}$ was $82.05 \%$.

The second leaching of the primary residue was operated for more $\mathrm{Mg}$ recovery. The influence of the main factors on the corresponding $\mathrm{Mg}$ extractions and $\mathrm{Mg}$ contents are presented in Figure 4.

It is not difficult to find that the influence of the main factors on the magnesium leaching rate was similar in the two leaching steps. The optimum sulfuric acid concentration for the second leaching step was also $2.4 \mathrm{~mol} / \mathrm{L}$. The influence of temperature on the secondary leaching process was stronger, and the leaching rate increased by $23.03 \%$ when the temperature was raised from $90{ }^{\circ} \mathrm{C}$ to $95^{\circ} \mathrm{C}$. The optimum liquid-solid ratio of the secondary process was $3 \mathrm{~mL} / \mathrm{g}$, which was lower than that of the primary acid leaching process, which occurred because there are fewer substances that can react with sulfuric acid in the primary acid leaching residue than the original ferronickel slag. The improvement in the second-stage acid leaching process by prolonging the leaching time was more obvious than in the first-stage acid leaching process. The leaching rate of the second-stage acid leaching process increased by $3.37 \%$ as the leaching time increased from $120 \mathrm{~min}$ to $150 \mathrm{~min}$. Overall, the optimum factors for second leaching were: acid concentration of $2.4 \mathrm{~mol} / \mathrm{L}$, leaching temperature of $95^{\circ} \mathrm{C}$, liquid-to-solid ratio of $3 \mathrm{~mL} / \mathrm{g}$, leaching time of $150 \mathrm{~min}$, stirring speed of $200 \mathrm{r} / \mathrm{min}$, and secondary $\mathrm{Mg}$ leaching percentage of $68.21 \%$, then the comprehensive leaching percentage of FNS was $94.29 \%$. 


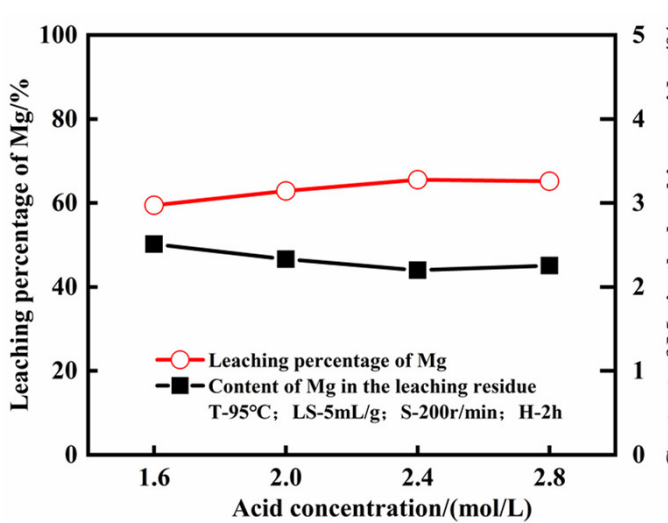

(a)

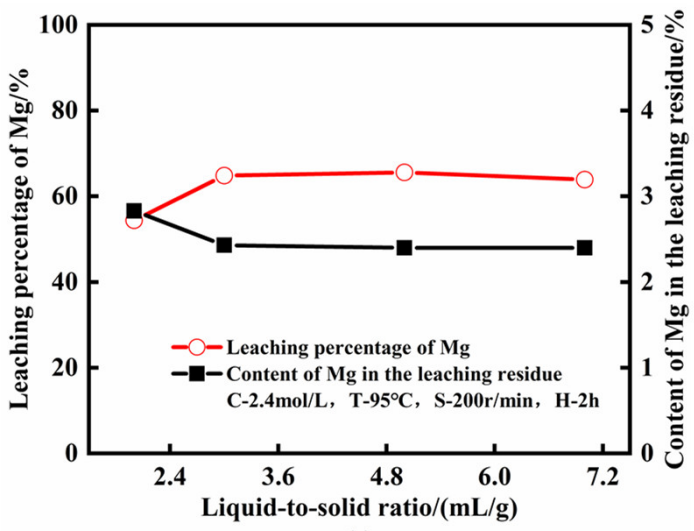

(c)

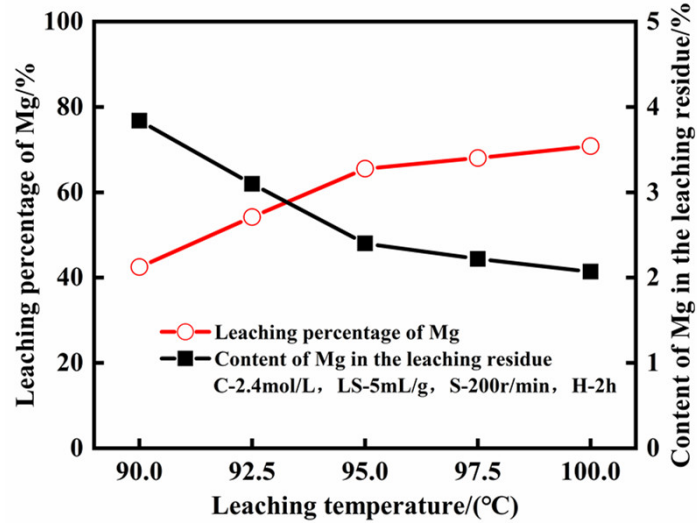

(b)

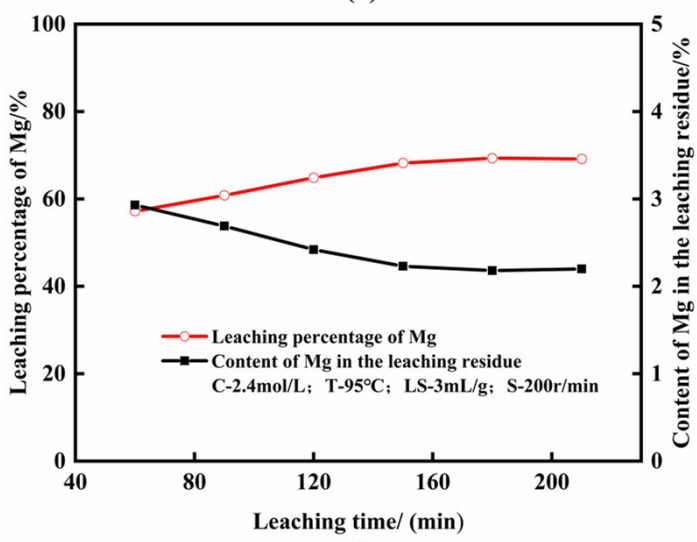

(d)

Figure 4. Influence of the main factors on the leaching rate of $\mathrm{Mg}$ in secondary acid leaching (a) acid concentration; (b) leaching temperature; (c) liquid-to-solid ration; (d) leaching time.

\subsection{Analysis of the Leaching Residues}

The XRF analysis results of leaching residues obtained under the optimized conditions are presented in Table 2. The main component in the residues changed to $\mathrm{SiO}_{2}$ after acid leaching, and the contents of other impurities were substantially low. The X-ray diffraction pattern of the residues (Figure 5) demonstrates that after the primary acid leaching process, the intensity of the diffraction peak of magnesium olivine evidently decreases, which indicates that most crystalline and glassy phases in the ferronickel slag have been leached out by acid. After the secondary acid leaching process, there was only a trace of quartz remaining, and the peak of magnesia olivine disappeared, which indicated that the minerals containing magnesium and iron in FNS basically reacted completely. The main component of the secondary acid leaching residue is purer amorphous silica, which seems to be more environmentally friendly and suitable for further disposal.

Table 2. XRF comparative analysis of the two stages acid leaching residue.

\begin{tabular}{cccccccccccc}
\hline Component & $\mathrm{SiO}_{\mathbf{2}}$ & $\mathbf{C a O}$ & $\mathbf{M g O}$ & $\mathbf{F e}_{\mathbf{2}} \mathbf{O}_{\mathbf{3}}$ & $\mathbf{A l}_{\mathbf{2}} \mathbf{O}_{\mathbf{3}}$ & $\mathbf{C r}_{\mathbf{2}} \mathbf{O}_{\mathbf{3}}$ & $\mathbf{M n O}$ & $\mathbf{T i O}_{\mathbf{2}}$ & $\mathbf{K}_{\mathbf{2}} \mathbf{O}$ & $\mathbf{N a}_{\mathbf{2}} \mathbf{O}$ & $\mathbf{N i O}$ \\
\hline The primary & 80.73 & 5.71 & 4.17 & 4.17 & 3.56 & 0.69 & 0.32 & 0.15 & 0.12 & 0.11 & 0.02 \\
The secondary & 84.20 & 5.54 & 2.28 & 3.32 & 3.14 & 0.59 & 0.27 & 0.13 & 0.11 & 0.09 & 0.01 \\
\hline
\end{tabular}




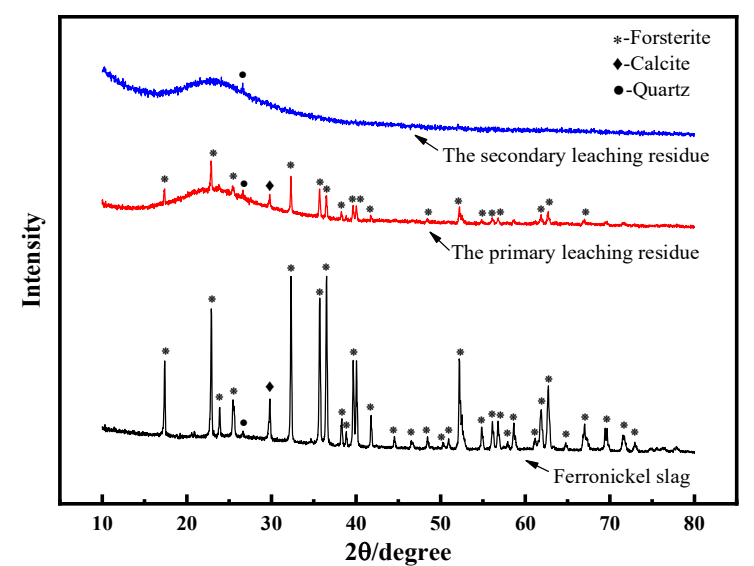

(a)

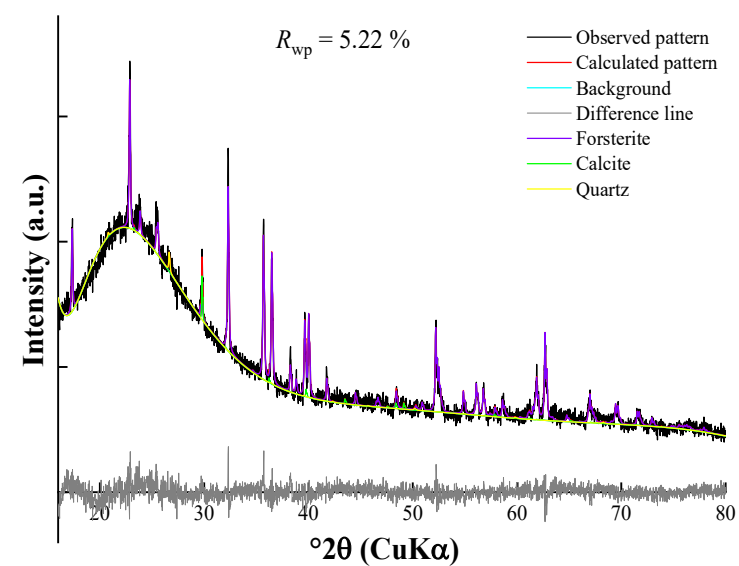

(b)

Figure 5. (a) XRD comparison of the FNS and acid leaching residues; (b) Rietveld XRD diagram of the primary leaching residue.

\subsection{Response Surface Optimization}

In order to optimize the process conditions and explore the main process factors and their interactions, response surface optimization was performed. In this study, the optimization of significant factors was performed via the response surface methodology (RSM). Table 3 summarizes the range of independent variables and their levels. Experiments were carried out according to the Box-Behnken design (BBD), as shown in Table 4.

Table 3. Experimental variables and levels used in the response surface design.

\begin{tabular}{ccccccccc}
\hline Code & Variables & Unit & \multicolumn{3}{c}{ Level } & \multicolumn{3}{c}{ Factor } \\
\hline A & acid concentration & $\mathrm{mol} / \mathrm{L}$ & 2.0 & 2.4 & 2.8 & -1 & 0 & +1 \\
B & reaction temperature & ${ }^{\circ} \mathrm{C}$ & 80 & 90 & 100 & -1 & 0 & +1 \\
$\mathrm{C}$ & reaction time & $\min$ & 90 & 120 & 150 & -1 & 0 & +1 \\
\hline
\end{tabular}

Table 4. Experimental scheme and results from the response surface designed experiment.

\begin{tabular}{ccccc}
\hline \multirow{2}{*}{ Number } & \multicolumn{3}{c}{ Variables } & Leaching Percentage of Mg/\% \\
\cline { 2 - 4 } & A & B & C & \\
\hline 1 & 2.8 & 90 & 150 & 83.49 \\
2 & 2.4 & 100 & 90 & 84.78 \\
3 & 2 & 100 & 120 & 83.67 \\
4 & 2.4 & 90 & 120 & 82.05 \\
5 & 2.4 & 100 & 150 & 86.77 \\
6 & 2.8 & 80 & 120 & 76.04 \\
7 & 2 & 80 & 120 & 75.26 \\
8 & 2.4 & 80 & 90 & 72.78 \\
9 & 2.8 & 100 & 120 & 84.35 \\
10 & 2.4 & 90 & 120 & 81.85 \\
11 & 2.8 & 90 & 90 & 80.33 \\
12 & 2 & 90 & 150 & 80.56 \\
13 & 2.4 & 80 & 150 & 76.22 \\
14 & 2 & 90 & 90 & 77.56 \\
15 & 2.4 & 90 & 120 & 83.01 \\
\hline
\end{tabular}


According to the experimental results in Table 4, the Design Expert software (Stat-Ease, Inc., 1300 Godward Street Northeast; Version 12.0.3) was used to execute the regression analysis, and the response surface equation of $\mathrm{Mg}$ leaching rate $\mathrm{R}$ was fitted as follows:

$$
\begin{aligned}
& R=-151.07583+34.28750 \mathrm{~A}+3.18963 \mathrm{~B}+0.350486 \mathrm{C}-\left(6.250 \times 10^{-3}\right) \mathrm{AB}-\left(3.333 \times 10^{-3}\right) \\
& \mathrm{AC}-\left(1.208 \times 10^{-3}\right) \mathrm{BC}-6.64323 \mathrm{~A}^{2}-0.014104 \mathrm{~B}^{2}-\left(8.39 \times 10^{-4}\right) \mathrm{C}^{2}
\end{aligned}
$$

(formula: A-acid concentration, $\mathrm{mol} / \mathrm{L}$; $\mathrm{B}$-reaction temperature, $\mathrm{C}$-reaction time, $\mathrm{min}$ ).

The coefficient of determination $\mathrm{R}^{2}$ of the above model is 0.9689 , which indicates that the fitted model is highly correlated [36].

Analysis of variance (ANOVA) was used to confirm the significance and adequacy of the quadratic response surface model. All observations with ANOVA are presented in Table 5. The F value of the regression model is 31.13 and $p$-value is 0.0029 . The results showed that the model was significant (highly significant: $p<0.001$; significant: $p<0.05$; not significant; $p>0.10$ ). Therefore, under a given level of the considered factors, the degree of influence of the three factors on the leaching rate of $\mathrm{Mg}$ is as follows: reaction temperature $>$ reaction time $>$ acid concentration. The change in sulfuric acid concentration (from $2 \mathrm{~mol} / \mathrm{L}$ to $2.8 \mathrm{~mol} / \mathrm{L}$ ) has a weak effect on the $\mathrm{Mg}$ leaching rate and increasing the reaction temperature (from $80^{\circ} \mathrm{C}$ to $100^{\circ} \mathrm{C}$ ) has a highly significant effect on the improvement in the $\mathrm{Mg}$ leaching rate. It can be considered that increasing the reaction temperature and appropriately extending the reaction time are the technical keys to improving the leaching effect of $\mathrm{Mg}$, while controlling the sulfuric acid concentration above $2 \mathrm{~mol} / \mathrm{L}$.

Table 5. ANOVA for the response surface quadratic model.

\begin{tabular}{ccccccc}
\hline Source & Sum of Square & Degree of Freedom & Mean Square & F-Value & $p$-Value & Significance Level \\
\hline Model & 228.48 & 9 & 25.39 & 17.31 & 0.0029 & significant \\
A-Acid concentration & 6.41 & 1 & 6.41 & 4.37 & 0.0908 & \\
B- & 192.77 & 1 & 192.77 & 131.46 & $<0.0001$ \\
Reactiontemperature & 16.79 & 1 & 16.79 & 11.45 & 0.0196 \\
C-Reaction time & 0.0025 & 1 & 0.0025 & 0.0017 & 0.9687 \\
AB & 0.0064 & 1 & 0.0064 & 0.0044 & 0.9499 \\
AC & 0.5256 & 1 & 0.5256 & 0.3585 & 0.5754 \\
BC & 4.17 & 1 & 4.17 & 2.84 & 0.1525 \\
A & 7.35 & 1 & 7.35 & 5.01 & 0.0754 \\
B $^{2}$ & 2.11 & 1 & 2.11 & 1.44 & 0.2843 \\
C $^{2}$ & 7.33 & 5 & 1.47 & & \\
Residual & 6.56 & 3 & 2.19 & 5.69 & 0.1531 \\
Lack of Fit & 0.7691 & 2 & 0.3845 & & not significant \\
Pure Error & 235.81 & 14 & & & \\
Cor Total & & & & & \\
\hline
\end{tabular}

The relationships between the three variables were resolved with the help of response surface plots, and the contour plots and 3D plots are displayed in Figure 6a-c. The significance of the interaction between the factors can be deduced by the shape of the contour lines (significant: elliptical; not significant: rounded), and the optimum range of the factors is reflected by the curvature of the response surface. According to Figure 6a, there is an optimal range for $\mathrm{Mg}$ leaching efficiency during an acid concentration of $2.4 \sim 2.6 \mathrm{~mol} / \mathrm{L}$ and a temperature of $95 \sim 100{ }^{\circ} \mathrm{C}$; moreover, there is a certain interaction between the two factors. The contour plots of Figure $6 \mathrm{~b}$ are elliptical, indicating that the interaction between the reaction temperature and time is significant, but the reaction time has a much milder effect. Figure $6 \mathrm{c}$ shows that the extraction rate of magnesium has difficulty reaching over $84 \%$ when the reaction temperature is fixed at $90{ }^{\circ} \mathrm{C}$. The interaction between acid concentration and reaction time is not significant because of the rounded contour plots. 


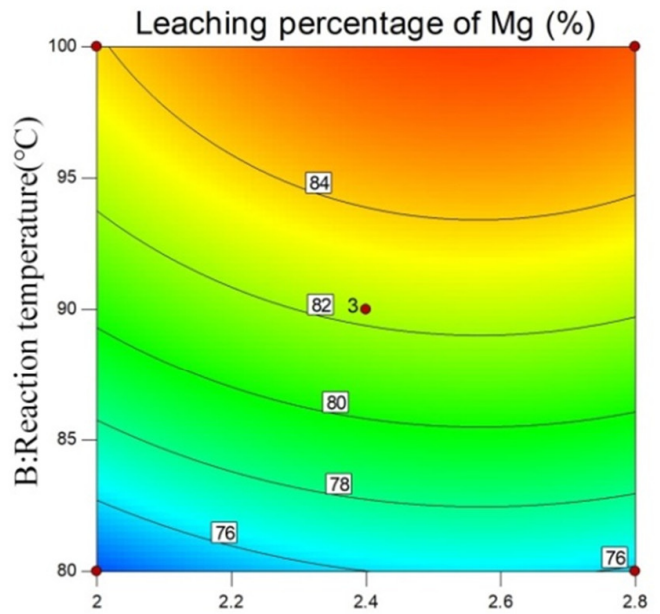

A: Acid concentration $(\mathrm{mol} / \mathrm{L})$

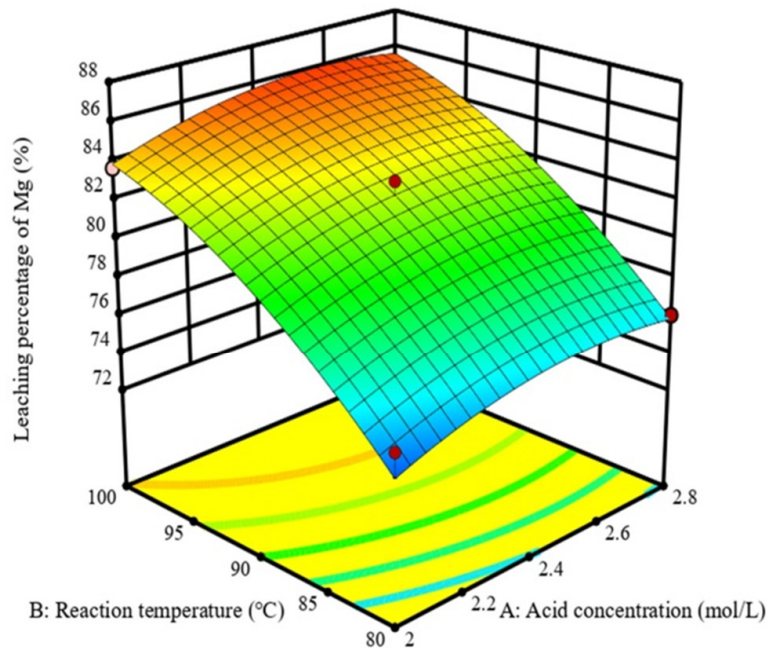

(a) Fixed reaction time $120 \mathrm{~min}$

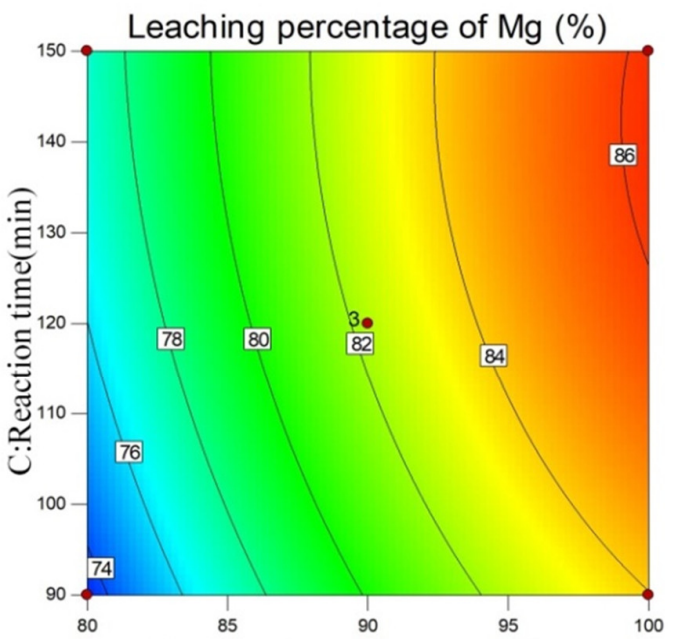

B: Reaction temperature $\left({ }^{\circ} \mathrm{C}\right)$

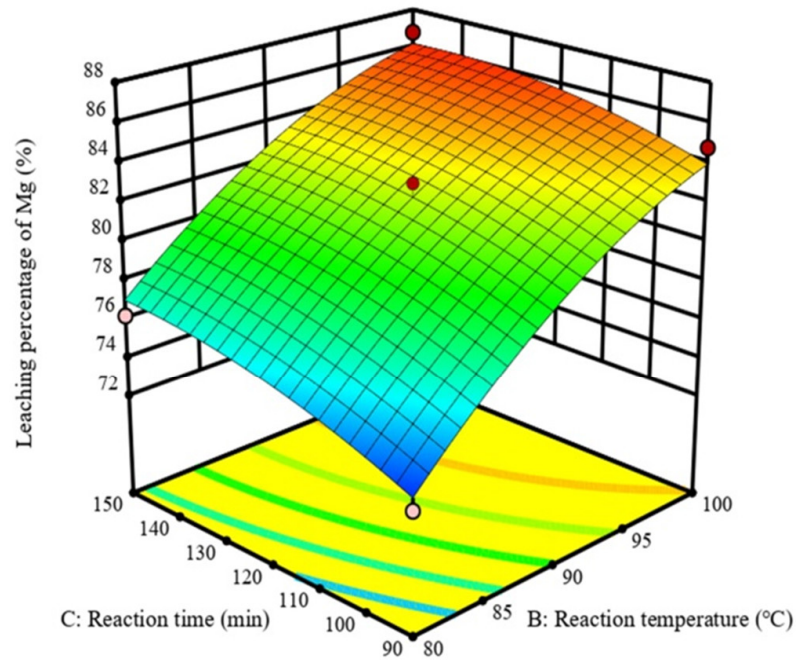

(b) Fixed acid concentration $2.4 \mathrm{~mol} / \mathrm{L}$
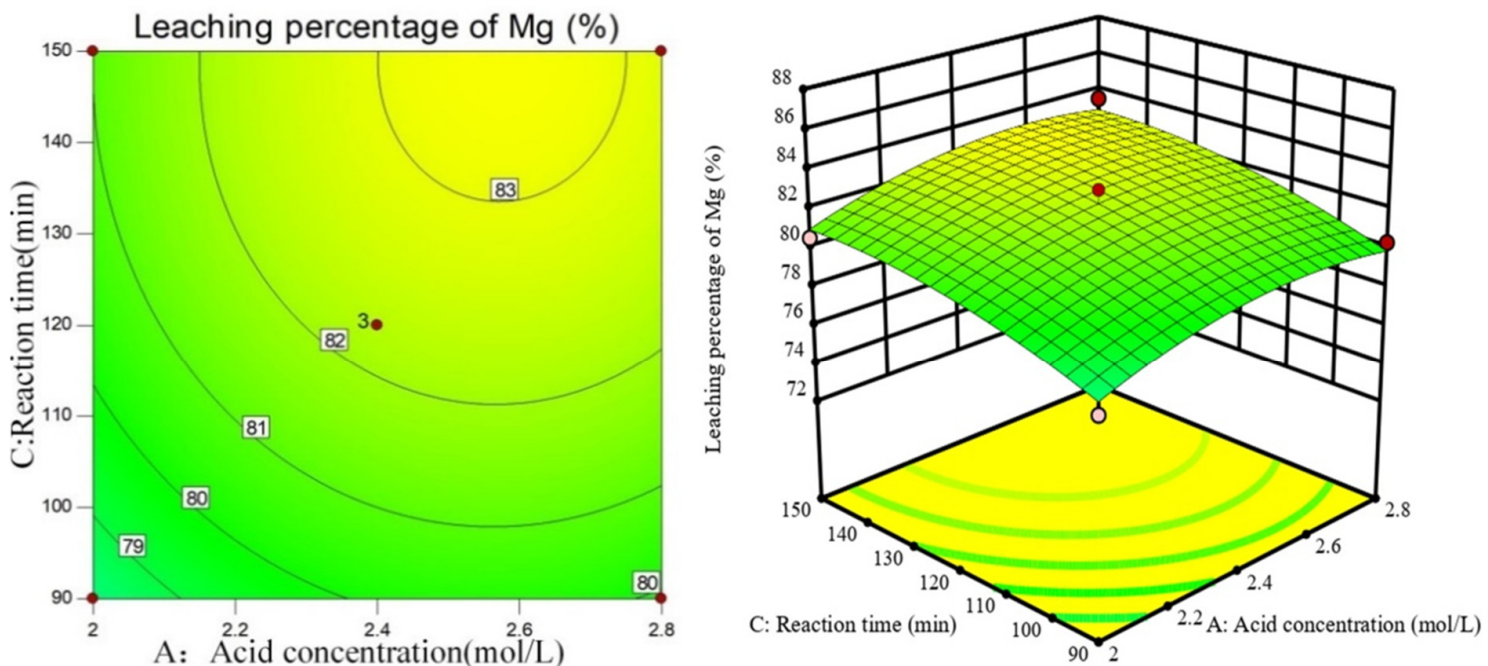

(c) Fixed reaction temperature $90^{\circ} \mathrm{C}$

Figure 6. The 3D plots and contour plots showing the effect of (a) acid concentration and reaction temperature, (b) reaction temperature and reaction time, and (c) reaction time and acid concentration. 
The most suitable conditions for primary acid leaching recommended by the response surface method are: acid concentration of $2.44 \mathrm{~mol} / \mathrm{L}$, reaction temperature of $96.11^{\circ} \mathrm{C}$, reaction time of $116.15 \mathrm{~min}$, and the predictive leaching rate of magnesium is $84.68 \%$. Considering the convenience of practical operation, the optimal process conditions were adjusted as follows: acid concentration of $2.4 \mathrm{~mol} / \mathrm{L}$, reaction temperature of $96^{\circ} \mathrm{C}$, and reaction time of $116 \mathrm{~min}$. The average leaching percentage of magnesium was $84.97 \%$ after three replicate validation experiments. Secondary leaching of the primary residue was also carried out, and the comprehensive Mg leaching percentage of FNS reached 95.82\%. The optimization was appreciable.

\subsection{Analysis of Leaching Kinetics}

Visual observations from the experiments showed that the leaching process followed the shrinkage-nuclear-reaction model. According to the leaching rate with reaction time at different reaction temperatures experimental data, the kinetics of magnesium leaching is analyzed, as shown in Figure 7a. Therefore, under the assumption that the sample is a homogeneous spherical solid phase, the chemical-reaction-controlled and diffusioncontrolled models can be represented by the following equations $[37,38]$ :

$$
\begin{gathered}
1-(1-\alpha)^{1 / 3}=\mathrm{k}_{1} \mathrm{t} \\
1-2 \alpha / 3-(1-\alpha)^{2 / 3}=\mathrm{k}_{2} \mathrm{t}
\end{gathered}
$$

where $\alpha$ is the leaching efficiency of magnesium, $\%, t$ is the leaching time, $\min , \mathrm{k}_{1}$ is the chemical reaction rate constant, $\min ^{-1}$, and $\mathrm{k}_{2}$ is the apparent rate constant of the internal diffusion-controlled model, $\min ^{-1}$.

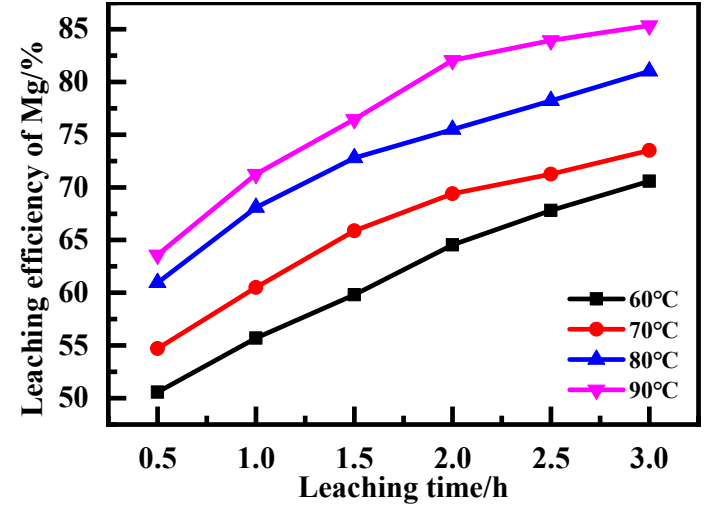

(a)

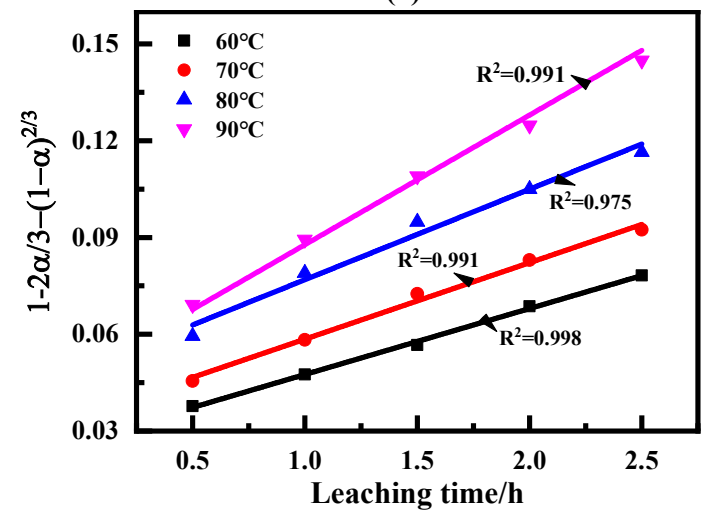

(c)

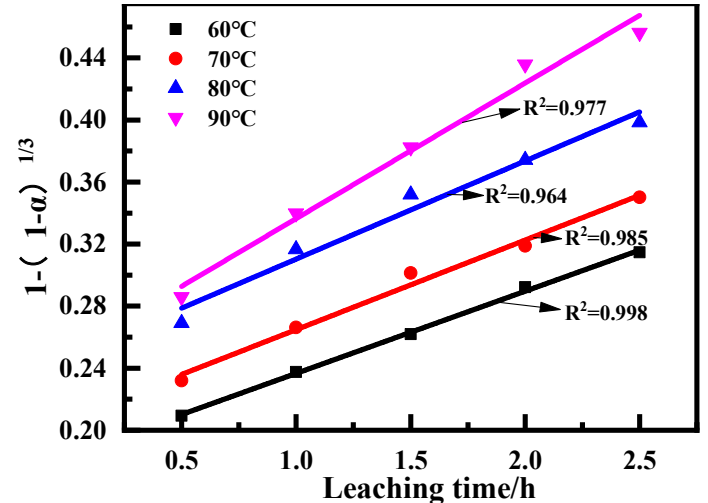

(b)

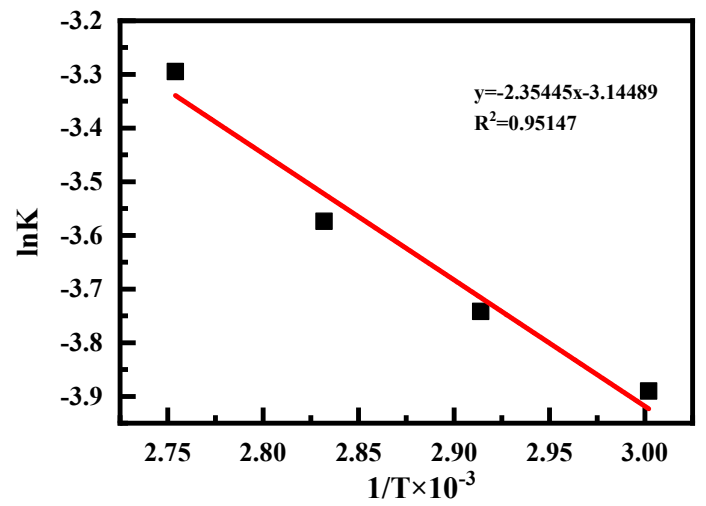

(d)

Figure 7. (a) Relationship between $\mathrm{Mg}$ leaching efficiency and leaching time; (b) plots of $1-(1-\alpha)^{1 / 3}$ vs. time for magnesium leaching; (c) plots of $1-2 \alpha / 3-(1-\alpha)^{2 / 3}$ vs. time for magnesium leaching; (d) Arrhenius plot of the solid membrane diffusion-controlled model. 
The curves in Figure $7 \mathrm{~b}$ exhibit a higher degree of deviation, indicating that the magnesium leaching process does not agree with the chemical reaction-controlled model. As shown in Figure 7c, during the initial $2.5 \mathrm{~h}$ leaching process, four straight lines that approach the zero point are observed, which are closer to the origin at low temperature $\left(60^{\circ} \mathrm{C}\right)$ and deviate from the origin at high temperature, demonstrating that the extraction is more likely controlled by diffusion through the solid membrane.

To calculate the activation energy of magnesium leaching, the Arrhenius equation was applied [39]:

$$
\ln \mathrm{K}=\ln \mathrm{A}-\mathrm{E} / \mathrm{RT}
$$

where $\mathrm{K}$ is the reaction rate constant, $\min ^{-1}, \mathrm{E}$ is the activation energy, $\mathrm{J} \cdot \mathrm{mol}^{-1}, \mathrm{~T}$ is the reaction temperature, $\mathrm{K}, \mathrm{R}$ is the gas constant with a value of $8.314 \mathrm{~J} \cdot \mathrm{K}^{-1} \cdot \mathrm{mol}^{-1}$, and $\mathrm{A}$ is the frequency factor.

A plot of $\operatorname{lnK}$ vs. $1 / \mathrm{T}$ for the diffusion-controlled model is linear, as presented in Figure $7 \mathrm{~d}$. The apparent activation energy (E) of $19.57 \mathrm{~kJ} \cdot \mathrm{mol}^{-1}$ was calculated from the slope of the line. It is inferred that the magnesium leaching process obeys composite control [39]. At low temperatures, the acid leaching reaction rate is slower and mainly controlled by chemical reactions. When the temperature rises to a certain value, the chemical reaction rate increases, resulting in an increase in the thickness of the product layer; the control step changes from chemical control to solid film diffusion control (mainly manifested as internal diffusion control). Therefore, thinning the solid film or accelerating the diffusion, such as by increasing the lixiviant concentration or decreasing the particle size of the solid, can be used to enhance the extraction of magnesium.

\subsection{Purification of Magnesium}

The two-stage acid leachates were mixed, and their metal ion composition is shown in Table 6. Besides $\mathrm{Mg}^{2+}$, the leaching solution contains $\mathrm{Fe}^{2+} / \mathrm{Fe}^{3+}, \mathrm{Al}^{3+}$, and $\mathrm{Cr}^{2+}$, which are impurities in the preparation of magnesium products. The quality of magnesium product vitally depends on the purity of the magnesium in the leachate; therefore, impurities should be removed as much as possible. Precipitation is a traditional impurity removal method; the theoretical basis is that different ions will be converted to metal hydroxide precipitation at different $\mathrm{pH}$ values of the solution, as shown in Table 7 [32]. Irons such as $\mathrm{Fe}^{3+}, \mathrm{Al}^{3+}$, and $\mathrm{Cr}^{3+}$ are relatively easy to be separated with $\mathrm{Mg}^{2+}$ due to their large and varying precipitation $\mathrm{pH}$ values, while $\mathrm{Fe}^{2+}$ and $\mathrm{Mn}^{2+}$ prevent the purification and recovery of $\mathrm{Mg}$, since the precipitation $\mathrm{pH}$ values of $\mathrm{Fe}^{2+}$ and $\mathrm{Mn}^{2+}$ overlap with that of $\mathrm{Mg}^{2+}$. Considering the low content of impurities, except for $\mathrm{Fe}$, it is difficult to remove all of them sequentially and the cost is high. Therefore, centralized removal is adopted in this study. $\mathrm{Fe}^{2+}$ and $\mathrm{Mn}^{2+}$ were first oxidized to $\mathrm{Fe}^{3+}$ and $\mathrm{MnO}_{2}$ with $\mathrm{H}_{2} \mathrm{O}_{2}$, then the leachate $\mathrm{pH}$ value was gradually adjusted to 7 by aqueous ammonia. Accordingly, most of the foreign ions could be separated as sediments from $\mathrm{Mg}^{2+}$, which remained in the liquid. Following this, the leachate underwent deep impurity removing by optimizing the $\mathrm{pH}$ value, react temperature, and time. The results are shown in Figure 8.

Table 6. Metal ion concentrations in leachates $(\mathrm{g} / \mathrm{L})$.

\begin{tabular}{cccccc}
\hline Metal Ion & $\mathbf{M g}^{2+}$ & $\mathrm{Fe}^{2+} / \mathrm{Fe}^{3+}$ & $\mathbf{A l}^{3+}$ & $\mathbf{C r}^{3+}$ & $\mathbf{M n}^{2+}$ \\
\hline Concentration & 9.76 & 1.72 & $0.8-0.6$ & $0.2-0.1$ & $<0.1$ \\
\hline
\end{tabular}

Table 7. $\mathrm{pH}$ of different metal ions upon hydroxide precipitation $\left(25^{\circ} \mathrm{C}\right)$.

\begin{tabular}{ccccccc}
\hline Ions & $\mathrm{Fe}^{3+}$ & $\mathbf{A l}^{3+}$ & $\mathbf{C r}^{3+}$ & $\mathbf{F e}^{2+}$ & $\mathbf{M n}^{2+}$ & $\mathbf{M g}^{2+}$ \\
\hline $\mathrm{pH}$ & $1.5-3.5$ & $3.1-5.1$ & $4-7$ & $6.3-9.3$ & $7.4-10.4$ & $8.4-11.4$ \\
\hline
\end{tabular}




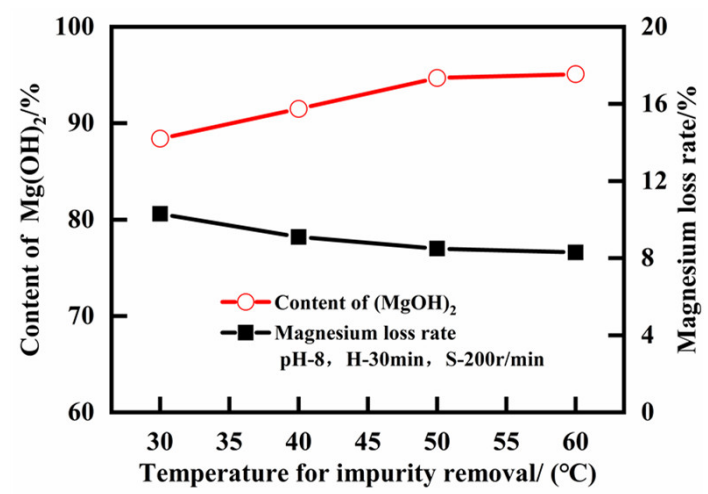

(a)

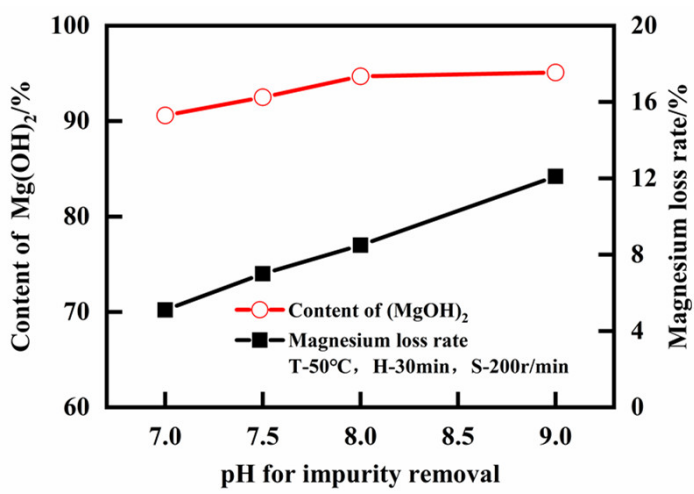

(b)

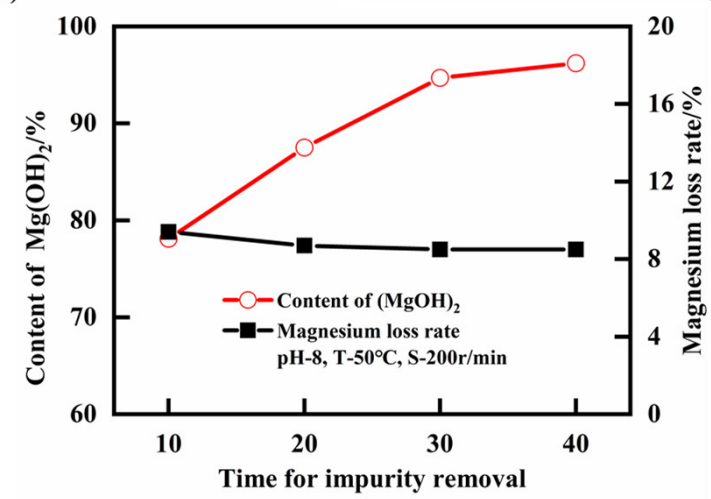

(c)

Figure 8. Impurity removal results of acid leachate (a) temperature for impurity removal; (b) pH for impurity removal; (c) time for impurity removal.

As shown in Figure 8a, increasing the reaction temperature can accelerate the precipitation and promote the generation of large-scale precipitates, thereby reducing the adsorption of $\mathrm{Mg}^{2+}$ by the precipitates and improving the subsequent solid-liquid separation effect. Thus, with the reaction temperature increase, $\mathrm{Mg}$ loss decreases, and the content of the intermediate product of $\mathrm{Mg}(\mathrm{OH})_{2}$ increases. However, this effect became considerably weak after $50{ }^{\circ} \mathrm{C}$. Therefore, the appropriate temperature for impurity removal was $50{ }^{\circ} \mathrm{C}$.

Figure $8 \mathrm{~b}$ illustrates that the $\mathrm{pH}$ value of the solution should be modest-the impurity ion precipitated incompletely at a lower $\mathrm{pH}$, resulting in a lower $\mathrm{Mg}(\mathrm{OH})_{2}$ content. Furthermore, when the $\mathrm{pH}$ was too high, a large amount of $\mathrm{Mg}^{2+}$ precipitated and the $\mathrm{Mg}$ loss in the solution increased. The optimum $\mathrm{pH}$ value for impurity removal was 8.0.

From Figure $8 c$, it can be concluded that the impurity removal time affected the sedimentation of impurity ions while having minimal effect on the $\mathrm{Mg}$ loss rate. The $\mathrm{Mg}(\mathrm{OH})_{2}$ content decreased when the removal time was no longer enough-owing to incomplete precipitation of impurity ions and large amounts of impurity ions remaining in the magnesium sulfate solution. After 30 min of impurity removal, the $\mathrm{Mg}(\mathrm{OH})_{2}$ content tended to be stable; therefore, the impurity removal time was fixed at $30 \mathrm{~min}$.

The chemical composition of the impurity removal residue is summarized in Table 8 after deep impurity removal under the above optimum conditions. The metal ion concentration of leachate after metal purification is shown in Table S1. It is shown that Fe, $\mathrm{Al}, \mathrm{Cr}$, and other elements are enriched in the debris, which creates conditions for their progressive recovery and utilization. After deep purification, the content of the intermediate product $\mathrm{Mg}(\mathrm{OH})_{2}$ of magnesium sulfate was $95.10 \%$, and the $\mathrm{Mg}$ loss rate was $8.5 \%$

Table 8. Elemental composition of impurity removal residue (\%).

\begin{tabular}{cccccccccc}
\hline Component & $\mathrm{Fe}_{2} \mathrm{O}_{3}$ & $\mathrm{Al}_{2} \mathrm{O}_{3}$ & $\mathrm{SiO}_{2}$ & $\mathrm{MgO}$ & $\mathrm{CaO}$ & $\mathrm{MnO}$ & $\mathrm{Cr}_{2} \mathrm{O}_{3}$ & $\mathrm{SO}_{3}$ & Others \\
\hline Content & 44.48 & 11.06 & 2.92 & 10.06 & 0.64 & 1.03 & 4.80 & 24.77 & 0.24 \\
\hline
\end{tabular}




\subsection{Preparation of Magnesium Oxide}

The alkaline magnesium carbonate calcination process was used to overcome the problems of high $\mathrm{S}$ content and bulk density of $\mathrm{MgO}$ products prepared by the conventional magnesium hydroxide calcination process [34]. Figure 9 illustrates the effect of the main technological conditions on the preparation of basic magnesium carbonate from purified magnesium sulfate solution.
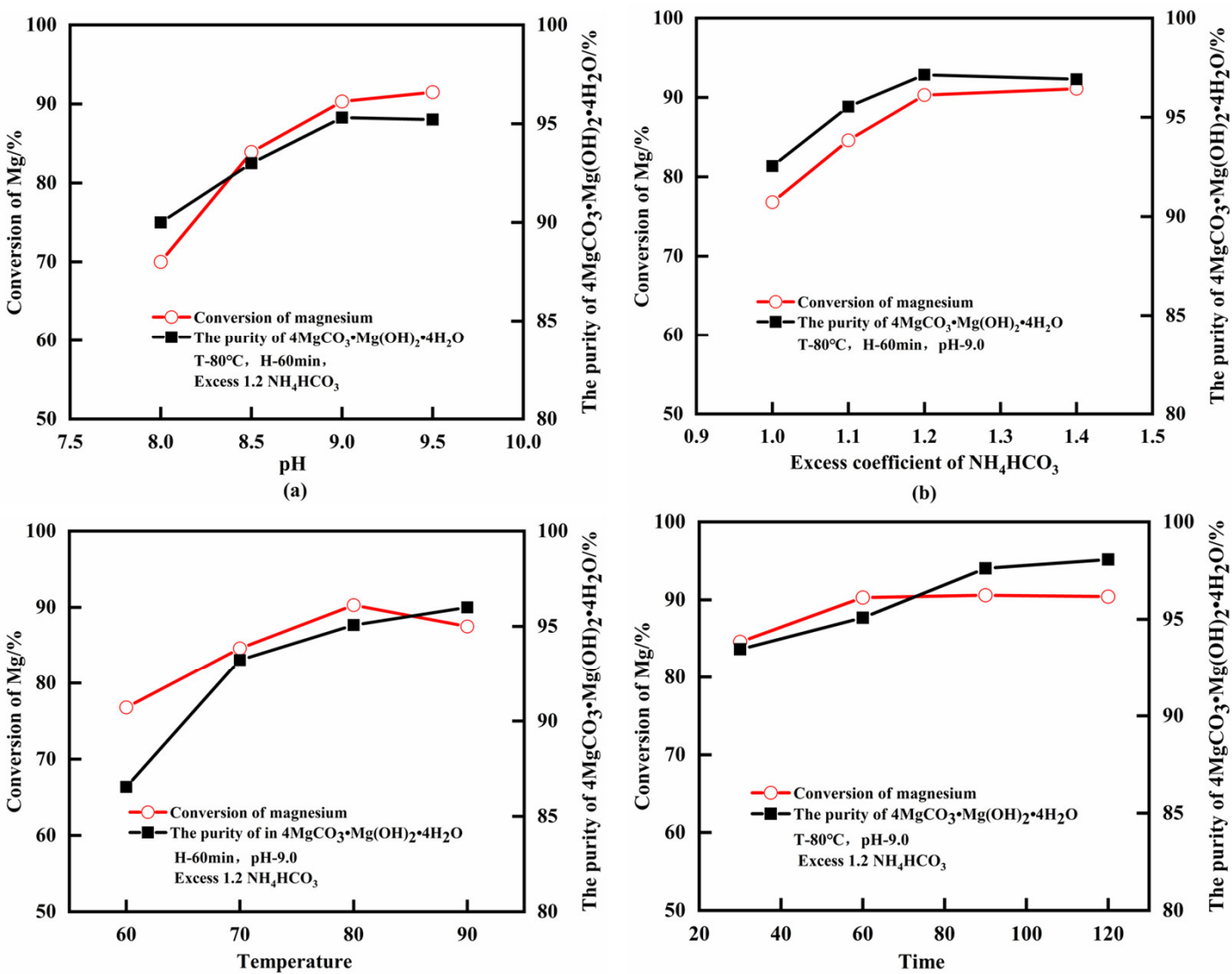

(c)

(d)

Figure 9. Effect of the main process conditions on magnesium precipitation efficacy (a) $\mathrm{pH}$; (b) excess coefficient of $\mathrm{NH}_{4} \mathrm{HCO}_{3}$; (c) temperature; (d) time. The purity of the precipitated products was calculated by the content of $\mathrm{Mg}$ found in the obtained precipitate vs the theoretical amount of $\mathrm{Mg}$ in $4 \mathrm{MgCO}_{3} \bullet \mathrm{Mg}(\mathrm{OH})_{2} \bullet 4 \mathrm{H}_{2} \mathrm{O}$.

The $\mathrm{Mg}$ conversion rate and purity of the precipitated products gradually increased with the increase in $\mathrm{pH}$ value. When the $\mathrm{pH}$ reached 9.0, the $\mathrm{Mg}$ conversion rate was $90.3 \%$, and the purity of the product was $95.08 \%$. Continuously increasing $\mathrm{pH}$ resulted in a slight increase in $\mathrm{Mg}$ conversion but a decrease in product purity (Figure 9a), indicating that low $\mathrm{pH}$ and an insufficient amount of ammonia led to incomplete precipitation of $\mathrm{Mg}^{2+}$, low product purity, and $\mathrm{Mg}$ conversion. However, if the $\mathrm{pH}$ is large enough, increasing the ammonia dosage will again promote the production of $\mathrm{Mg}(\mathrm{OH})_{2}$ precipitate (milk-white precipitate has been observed at $\mathrm{pH}=9.5$ ), and the adsorption of ions in the solution by $\mathrm{Mg}(\mathrm{OH})_{2}$ exist in colloidal form, which will affect the production and quality of basic magnesium carbonate, which is also unfavorable to the subsequent product filtration and washing [34]. The optimal $\mathrm{pH}$ was determined to be 9.0, corresponding to an ammonia addition of $2 \mathrm{~mL}$.

The effect of the $\mathrm{NH}_{4} \mathrm{HCO}_{3}$ content on the production of basic magnesium carbonate is shown in Figure 9b. When the excess coefficient of $\mathrm{NH}_{4} \mathrm{HCO}_{3}$ is 1.0-1.2, purity and magnesium conversion of the precipitates increase with the excess coefficient. Moreover, when the excess coefficient reached 1.3, the purity in the precipitates decreased and the magnesium conversion was basically unchanged. It can be observed that sufficient $\mathrm{NH}_{4} \mathrm{HCO}_{3}$ is 
a necessity for the complete conversion of $\mathrm{Mg}^{2+}$ into basic magnesium carbonate; however, when $\mathrm{NH}_{4} \mathrm{HCO}_{3}$ is in excess, it causes incomplete dissolution, which is unfavorable to the reaction. Therefore, an excess coefficient of 1.2 was chosen for $\mathrm{NH}_{4} \mathrm{HCO}_{3}$.

Figure $9 \mathrm{c}$ shows that the magnesium precipitation reaction needs to be carried out at a certain temperature. Low temperature led to a slow reaction speed, and ammonia volatilized retarding the reaction when the temperature was too high (Equation (5)). In addition, the formation of basic magnesium carbonate was hindered due to a portion of $\mathrm{Mg}^{2+}$ converting to $\mathrm{Mg}\left(\mathrm{HCO}_{3}\right)_{2}$ or $\mathrm{MgCO}_{3} \bullet 3 \mathrm{H}_{2} \mathrm{O}$ [34]. These all led to a decrease in $\mathrm{Mg}$ conversion and product purity; therefore, $80^{\circ} \mathrm{C}$ is the comparative suitable reaction temperature.

The results shown in Figure $9 \mathrm{~d}$ suggest that increasing the reaction time had a beneficial effect on the purity of the product and the conversion of magnesium; however, the effect on the product's purity was more obvious. After $60 \mathrm{~min}$ reaction, the $\mathrm{Mg}^{2+}$ in the solution completely participated in the reaction, and the $\mathrm{Mg}$ conversion no longer changed. When the reaction time was continued to $90 \mathrm{~min}$, and the reaction was dominated by the conversion of intermediate products such as $\mathrm{Mg}\left(\mathrm{HCO}_{3}\right)_{2}$ or $\mathrm{MgCO}_{3} \bullet 3 \mathrm{H}_{2} \mathrm{O}$ rather than basic magnesium carbonate, the purity of the products was further improved. An optimal reaction time of $90 \mathrm{~min}$ was experimentally determined.

In summary, the purity of the magnesium precipitation product obtained under optimal conditions was $97.62 \%$, and the Mg conversion rate was $90.6 \%$. The XRD and SEM analysis of magnesium precipitation products are shown in Figure 10. The XRD patterns were in agreement with PDF card $25-0513\left(4 \mathrm{MgCO}_{3} \bullet \mathrm{Mg}(\mathrm{OH})_{2} \bullet 4 \mathrm{H}_{2} \mathrm{O}\right)$, which proved that the product was basic magnesium carbonate. In addition, the intensity of XRD peaks was high and the shape of peaks was sharp, indicating high purity. From the SEM image, it can be clearly seen that this basic magnesium carbonate is a spherical particle with a diameter of about $510 \mu \mathrm{m}$; the particle size was uniform, the product was purer, and there were fewer residual impurities on the particle surface. The produced basic magnesium carbonate can be used as a raw material for the preparation of $\mathrm{MgO}$, and can also be used as a final product with a flexible process.

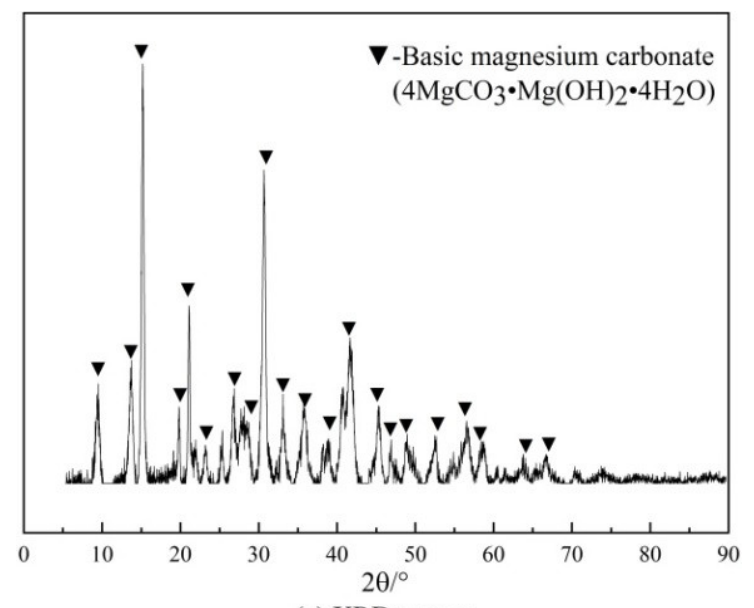

(a) XRD pattern

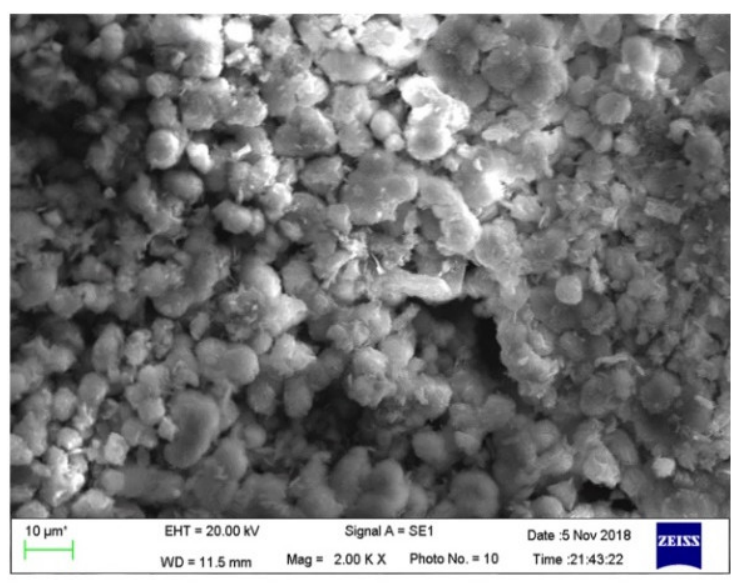

(b) SEM Image

Figure 10. Analysis of magnesium precipitation product (a) XRD pattern; (b) SEM image.

A powdery material was obtained by calcining the basic magnesium carbonate at $900{ }^{\circ} \mathrm{C}$ for $90 \mathrm{~min}$. The color of the powder was white, which is consistent with the appearance characteristics of magnesium oxide. The XRD and SEM of the powder are shown in Figure 11. The XRD pattern was highly consistent with the PDF card -\#45-0946 (MgO), and no other impurity peaks were found, indicating that the main chemical composition of the powder was $\mathrm{MgO}$. The SEM images of the powder show that the size of the powder particles is about $2-5 \mu \mathrm{m}$ with a rod shape, and the surface of the particles is loose, which implies the bulk density of the powder is relatively low. The result of EDS analysis further confirmed that the powder was light magnesium oxide with high purity. Other quality 
indicators of $\mathrm{MgO}$ powder are shown in Table 9. The quality of the powder meets the national industrial magnesium oxide standard, and the profit of this preparation process is considerable (Table S2).

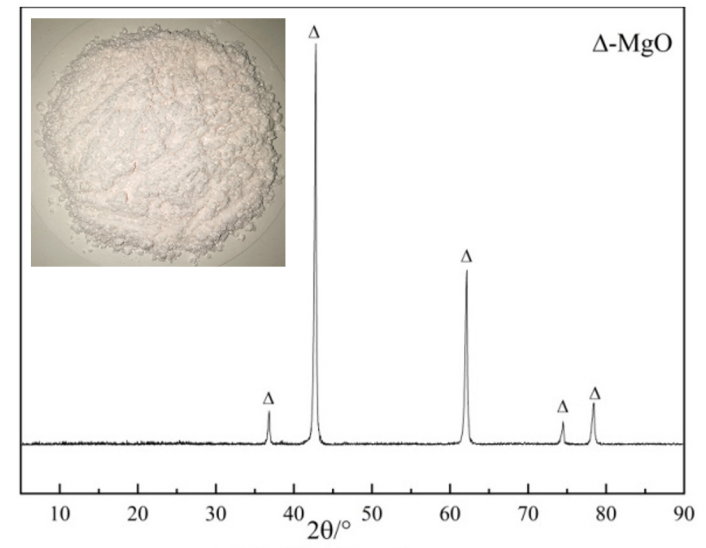

(a) $\mathrm{MgO}$ XRD pattern
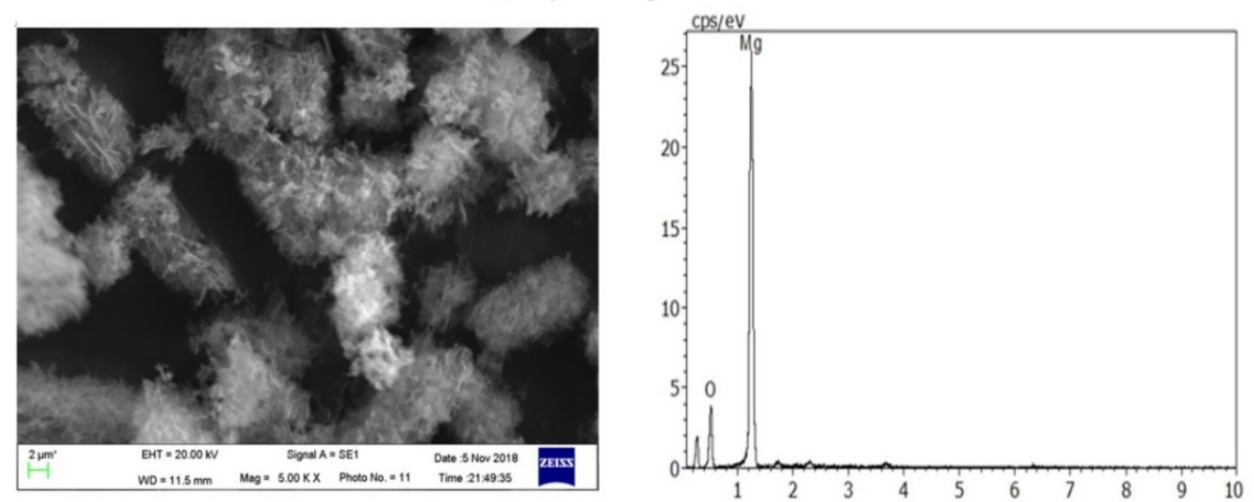

(b) SEM-EDS Images

Figure 11. Analysis of calcined product (a) MgO XRD pattern; (b) SEM-EDS images.

Table 9. Chinese industry standard for first-class magnesia index and product indexes.

\begin{tabular}{|c|c|c|c|c|c|c|c|c|c|}
\hline Project & $\underset{/ \%}{\mathrm{MgO}}$ & $\begin{array}{c}\mathrm{CaO} \\
/ \%\end{array}$ & $\begin{array}{c}\mathrm{HCl} \\
\text { Insoluble/\% }\end{array}$ & $\begin{array}{c}\text { Sulfate } \\
/ \%\end{array}$ & $\begin{array}{c}150 \mu \mathrm{m} \\
\text { Residue on } \\
\text { Sieve/\% }\end{array}$ & $\begin{array}{l}\mathrm{Fe} \\
/ \%\end{array}$ & $\begin{array}{l}\mathrm{Mn} \\
/ \%\end{array}$ & $\begin{array}{c}\text { Loss on } \\
\text { Ignition/\% }\end{array}$ & $\begin{array}{c}\text { Bulk } \\
\text { Density } \\
/(\mathrm{g} / \mathrm{mL})\end{array}$ \\
\hline First-class & $\geq 93.0$ & $\leq 1.5$ & $\leq 0.20$ & $\leq 0.6$ & $\leq 0.03$ & $\leq 0.06$ & $\leq 0.01$ & $\leq 5.0$ & $\leq 0.20$ \\
\hline Product & 94.85 & 0.8 & trace & 0.48 & trace & 0.014 & 0.008 & 3.10 & 0.16 \\
\hline
\end{tabular}

\section{Conclusions}

The present study proposed a mild and efficient route for the recovery of magnesium from ferronickel slag to prepare magnesium oxide.

(1) The results of the mineralogical analysis showed that the main chemical components of the FNS were $\mathrm{SiO}_{2}, \mathrm{MgO}$, and $\mathrm{Fe}_{2} \mathrm{O}_{3}$, mainly in forsterite form, with strong crystallinity and leaching out difficulty. The single factor acid leaching experiments showed that grinding fineness, acid concentration, liquid-to-solid ratio, leaching temperature, leaching time, and stirring speed all had an impact on the leaching of $\mathrm{Mg}$. The influence of acid leaching temperature, acid leaching time, and acid concentration were more prominent. The maximum leaching rate of $\mathrm{Mg}$ in the primary acid leaching was $82.05 \%$ and increased by $12.24 \%$ after the secondary acid leaching. Therefore, a two-step leaching process is recommended. 
(2) The response surface analysis showed that when the sulfuric acid concentration was controlled above $2 \mathrm{~mol} / \mathrm{L}$, the degree of influence of the following three factors on the magnesium leaching rate were: reaction temperature $>$ reaction time $>$ acid concentration. In addition, there is a certain interaction between the leaching temperature and the leaching time. Combining the single factor experiment with response surface optimization, the optimum process conditions for acid leaching are as follows: in the two-step leaching process, the FNS grinding fineness of $-0.074 \mathrm{~mm}$ accounted for $94.5 \%$, the acid concentration was $2.4 \mathrm{~mol} / \mathrm{L}$, the leaching temperature was $96^{\circ} \mathrm{C}$, and the stirring speed was $200 \mathrm{r} / \mathrm{min}$; the liquid-to-solid ratios in the primary and secondary processes were $6 \mathrm{~mL} / \mathrm{g}$ and $3 \mathrm{~mL} / \mathrm{g}$; the leaching times in the first and second stage were $120 \mathrm{~min}$ and $150 \mathrm{~min}$, respectively. The comprehensive magnesium leaching rate from ferronickel slag reached 95.82\% (84.97\% for primary leaching and $72.19 \%$ for secondary leaching).

(3) The acid leaching kinetics study showed that the atmospheric sulfuric acid leaching of magnesium from FNS satisfied the mixed control model. The surface chemical is dominant at low temperatures and turns to film diffusion control at high temperatures. Therefore, reducing the particle size of the FNS and increasing the reaction temperature are important for improving the $\mathrm{Mg}$ leaching effect.

(4) Due to the low content of other impurities in the acid leaching solution, (except for $\mathrm{Mg}$ ), this study prefers to use a centralized exclusion process to remove impurities. After pre-oxidation, pre-purification, and deep impurity removal $\left(50^{\circ} \mathrm{C}, \mathrm{pH}=8,30 \mathrm{~min}\right)$ processes, most of the impurities were removed; the content of intermediate product $\mathrm{Mg}(\mathrm{OH})_{2}$ of magnesium sulfate solution was $95.10 \%$, and the $\mathrm{Mg}$ loss was $8.5 \%$. Basic magnesium carbonate was prepared by the mixed ammonia precipitation method, and the optimum process conditions were as follows: $\mathrm{pH}=9.0, \mathrm{NH}_{4} \mathrm{HCO}_{3}$ excess coefficient of $1.2,80^{\circ} \mathrm{C}, 90 \mathrm{~min}$, and the $\mathrm{Mg}$ conversion was $90.6 \%$. The results of XRD and SEM analyses showed that the alkali magnesium carbonate obtained in the experiment consisted of spherical particles with a diameter of 5-10 $\mu \mathrm{m}$, and with high purity ( $\mathrm{MgO}$ of $42.3 \%$ ). The white powders obtained by $900{ }^{\circ} \mathrm{C}$ roasting $90 \mathrm{~min}$ of basic magnesium carbonate are $\mathrm{MgO}$, which is characterized by a diameter of about $2-5 \mu \mathrm{m}$, with rod shape and loose surface. The quality of the powder reached the first-grade standard of $\mathrm{MgO}$ for industrial use in China.

Supplementary Materials: The following are available online at https:/ /www.mdpi.com/article/10 $.3390 / \min 11121375 / \mathrm{s} 1$, Table S1: metal ion concentrations for the leachate after metals purification $(\mathrm{g} / \mathrm{L})$; Table S2: table of economic summary for the treatment of $1 \mathrm{t}$ ferronickel slag.

Author Contributions: Writing, formal analysis, and original draft preparation, J.Y.; conceptualization, review, and revision, X.D.; design and experiments, L.L.; supervision, H.Y.; investigation, X.J. This was a joint work of the five authors; each author was in charge of their expertise and capability. All authors have read and agreed to the published version of the manuscript.

Funding: This research received no external funding.

Acknowledgments: We would like to express our sincere appreciation to the anonymous reviewers for their insightful comments, which helped us improve the quality of this paper. We thanked Tangshan Boquan Industrial Co., Ltd. for its experimental raw materials support in project research.

Conflicts of Interest: The authors declare no conflict of interest.

\section{References}

1. Luo, J.; Li, G.; Rao, M.; Zhang, Y.; Peng, Z.; Zhi, Q.; Jiang, T. Evaluation of Sintering Behaviors of Saprolitic Nickeliferous Laterite Based on Quaternary Basicity. JOM 2015, 67, 1966-1974. [CrossRef]

2. Saha, A.K.; Sarker, P.K. Expansion due to alkali-silica reaction of ferronickel slag fine aggregate in OPC and blended cement mortars. Constr. Build. Mater. 2016, 123, 135-142. [CrossRef]

3. Peng, Z.; Wang, L.; Gu, F.; Tang, H.; Rao, M.; Zhang, Y.; Li, G.; Jiang, T. Recovery of chromium from ferronickel slag: A comparison of microwave roasting and conventional roasting strategies. Powder Technol. 2020, 372, 578-584. [CrossRef]

4. Zhang, Z.; Zhu, Y.; Yang, T.; Li, L.; Zhu, H.; Wang, H. Conversion of local industrial wastes into greener cement through geopolymer technology: A case study of high-magnesium nickel slag. J. Clean. Prod. 2017, 141, 463-471. [CrossRef] 
5. Saha, A.K.; Sarker, P.K. Sustainable use of ferronickel slag fine aggregate and fly ash in structural concrete: Mechanical properties and leaching study. J. Clean. Prod. 2017, 162, 438-448. [CrossRef]

6. Choi, Y.C.; Choi, S. Alkali-silica reactivity of cementitious materials using ferro-nickel slag fine aggregates produced in different cooling conditions. Constr. Build. Mater. 2015, 99, 279-287. [CrossRef]

7. Saha, A.K.; Sarker, P.K.; Golovanevskiy, V. Thermal properties and residual strength after high temperature exposure of cement mortar using ferronickel slag aggregate. Constr. Build. Mater. 2019, 199, 601-612. [CrossRef]

8. Pan, J.; Zheng, G.L.; Zhu, D.Q.; Zhou, X.L. Utilization of nickel slag using selective reduction followed by magnetic separation. Trans. Nonferrous Met. Soc. China 2013, 23, 3421-3427. [CrossRef]

9. Komnitsas, K.; Zaharaki, D.; Bartzas, G. Effect of sulphate and nitrate anions on heavy metal immobilisation in ferronickel slag geopolymers. Appl. Clay Sci. 2013, 73, 103-109. [CrossRef]

10. Ljatifi, E.; Kamusheva, A.; Grozdanov, A.; Paunović, P.; Karamanov, A. Optimal thermal cycle for production of glass-ceramic based on wastes from ferronickel manufacture. Ceram. Int. 2015, 41, 11379-11386. [CrossRef]

11. Karamanov, A.; Paunović, P.; Ranguelov, B.; Ljatifi, E.; Kamusheva, A.; Načevski, G.; Karamanova, E.; Grozdanov, A. Vitrification of hazardous Fe-Ni wastes into glass-ceramic with fine crystalline structure and elevated exploitation characteristics. J. Environ. Chem. Eng. 2017, 5, 432-441. [CrossRef]

12. Wang, W.; Chen, J.; Yu, J.; Zhou, L.; Dai, S.; Tian, W. Adjusting the melting and crystallization behaviors of ferronickel slag via partially replacing of $\mathrm{SiO} 2$ by $\mathrm{B} 2 \mathrm{O} 3$ for mineral wool production. Waste Manag. 2020, 111, 34-40. [CrossRef]

13. Gu, F.; Peng, Z.; Zhang, Y.; Tang, H.; Ye, L.; Tian, W.; Liang, G.; Rao, M.; Li, G.; Jiang, T. Facile Route for Preparing Refractory Materials from Ferronickel Slag with Addition of Magnesia. ACS Sustain. Chem. Eng. 2018, 6, 4880-4889. [CrossRef]

14. Peng, Z.; Tang, H.; Augustine, R.; Lee, J.; Tian, W.; Chen, Y.; Gu, F.; Zhang, Y.; Li, G.; Jiang, T. From ferronickel slag to value-added refractory materials: A microwave sintering strategy. Resour. Conserv. Recycl. 2019, 149, 521-531. [CrossRef]

15. Gu, F.; Peng, Z.; Zhang, Y.; Tang, H.; Tian, W.; Lee, J.; Rao, M.; Li, G.; Jiang, T. Promoting spinel formation and growth for preparation of refractory materials from ferronickel slag. Int. J. Appl. Ceram. Technol. 2020, 17, 1701-1712. [CrossRef]

16. Liu, K. The Study on the Preparation of Forsterite Refractories from High Magnesium Nickel Slag; University of Science and Technology: Beijing, China, 2018; pp. 1-76.

17. Wang, Y.; Zhu, R.; Chen, Q.; Wei, G.; Hu, S.; Guo, Y. Recovery of Fe, Ni, Co, and Cu from nickel converter slag through oxidation and reduction. ISIJ Int. 2018, 58, 2191-2199. [CrossRef]

18. Huang, F.; Liao, Y.; Zhou, J.; Wang, Y.; Li, H. Selective recovery of valuable metals from nickel converter slag at elevated temperature with sulfuric acid solution. Sep. Purif. Technol. 2015, 156, 572-581. [CrossRef]

19. Tian, D.; Shen, X.; Zhai, Y.; Xiao, P.; Webley, P. Extraction of iron and aluminum from high-iron bauxite by ammonium sulfate roasting and water leaching. J. Iron Steel Res. Int. 2019, 26, 578-584. [CrossRef]

20. Zhai, X.J.; Li, N.J.; Zhang, X.; Fu, Y.; Jiang, L. Recovery of cobalt from converter slag of Chambishi Copper Smelter using reduction smelting process. Trans. Nonferrous Met. Soc. China 2011, 21, 2117-2121. [CrossRef]

21. Li, Y.; Perederiy, I.; Papangelakis, V.G. Cleaning of waste smelter slags and recovery of valuable metals by pressure oxidative leaching. J. Hazard. Mater. 2008, 152, 607-615. [CrossRef]

22. Gbor, P.K.; Ahmed, I.B.; Jia, C.Q. Evaluation of contributions of acid and ligand to Ni, Co, and Fe dissolution from nonferrous smelter slags in aqueous sulfur dioxide. Ind. Eng. Chem. Res. 2002, 41, 1861-1867. [CrossRef]

23. Perederiy, I.; Papangelakis, V.G.; Buarzaiga, M.; Mihaylov, I. Co-treatment of converter slag and pyrrhotite tailings via high pressure oxidative leaching. J. Hazard. Mater. 2011, 194, 399-406. [CrossRef] [PubMed]

24. Curlook, W.; Baghalha, M.; Papangelakis, V.; Curlook, W.; Baghalha, M.; Papangelakis, V. Process for the Recovery of Residual Metal Values from Smelter Waste Slags, and from Converter Slags. CA2363969 C, 13 January 2001.

25. Altinkaya, P.; Mäkinen, J.; Kinnunen, P.; Kolehmainen, E.; Haapalainen, M.; Lundström, M. Effect of biological pretreatment on metal extraction from flotation tailings for chloride leaching. Miner. Eng. 2018, 129, 47-53. [CrossRef]

26. Bulaev, A.G.; Muravyov, M.I.; Pivovarova, T.A.; Fomchenko, N.V.; Kondrat'eva, T.F. Bioprocessing of mining and metallurgical wastes containing nonferrous and precious metals. Adv. Mater. Res. 2013, 825, 301-304. [CrossRef]

27. Zhang, X.; Gu, F.; Peng, Z.; Wang, L.; Tang, H.; Rao, M.; Zhang, Y.; Li, G.; Jiang, T.; Wang, Y. Recovering Magnesium from Ferronickel Slag by Vacuum Reduction: Thermodynamic Analysis and Experimental Verification. ACS Omega 2019, 4, 16062-16067. [CrossRef]

28. Zhao, C.; Cai, Y.; Ning, Z.; Wang, G.; Kang, S.; Zhang, C.; Zhai, Y. Recovery of MgO from laterite nickel slag through roasting by ammonium sulfate. Zhongnan Daxue Xuebao (Ziran Kexue Ban)/J. Cent. South Univ. (Sci. Technol.) 2017, 48, 1972-1978. [CrossRef]

29. Prasetyo, A.B.; Rahadian, D.; Mayangsari, W.; Febriana, E.; Permana, S.; Maksum, A.; Soesaptri, O.; Firdiyono, F.; Soedarsono, J.W. Reverse leaching of magnesium from ferronickel slag using alkali solvent naoh. Eastern-Eur. J. Enterp. Technol. 2020, 1, 6-14. [CrossRef]

30. Mubarok, M.Z.; Yudiarto, A. Synthesis of Magnesium Oxide from Ferronickel Smelting Slag through Hydrochloric Acid LeachingPrecipitation and Calcination; Springer: Berlin/Heidelberg, Germany, 2017.

31. Gao, F.; Huang, Z.; Li, H.; Li, X.; Wang, K.; Hamza, M.F.; Wei, Y.; Fujita, T. Recovery of magnesium from ferronickel slag to prepare hydrated magnesium sulfate by hydrometallurgy method. J. Clean. Prod. 2021, 303, 127049. [CrossRef]

32. Linchuan, L. The Study on the Comprehensive Utilization and Recovery of Valuable Components from Electric Furnace NickelIron Slag. Master's Thesis, University of Science and Technology, Beijing, China, 2018; pp. 1-79. 
33. Bergmann, J.; Friedel, P.; Kleeberg, R. BGMN-A New Fundamental Parameters Based Rietveld Program for Laboratory X-ray Sources, it's Use in Quantitative Analysis and Structure Investigations. IUCr Comm. Powder Diffr. Newsl. 1998, 20, 5-8.

34. Xu, H.; Liu, W.P.; Yang, X.Y.; Shi, X.C.; Chen, S.Y.; Yu, L.L. Preparation of high-purity light magnesia from sulfate salt subtype salt lake brine. Zhongnan Daxue Xuebao (Ziran Kexue Ban)/J. Cent. South Univ. (Sci. Technol.) 2011, 42, 2204-2208.

35. Huang, J.; Chen, M.; Chen, H.; Chen, S.; Sun, Q. Leaching behavior of copper from waste printed circuit boards with Brønsted acidic ionic liquid. Waste Manag. 2014, 34, 483-488. [CrossRef] [PubMed]

36. Khatoon, H.; Rai, J.P.N. Optimization studies on biodegradation of atrazine by Bacillus badius ABP6 strain using response surface methodology. Biotechnol. Rep. 2020, 26, e00459. [CrossRef] [PubMed]

37. Apostolidis, C.I.; Distin, P.A. The kinetics of the sulphuric acid leaching of nickel and magnesium from reduction roasted serpentine. Hydrometallurgy 1978, 3, 181-196. [CrossRef]

38. Hollagh, A.R.E.; Alamdari, E.K.; Moradkhani, D.; Salardini, A.A. Kinetic Analysis of Isothermal Leaching of Zinc from Zinc Plant Residue. Int. J. Nonferrous Metall. 2013, 2, 10-20. [CrossRef]

39. Lin, Q.; Gu, G.; Wang, H.; Zhu, R.; Liu, Y.; Fu, J. Preparation of manganese sulfate from low-grade manganese carbonate ores by sulfuric acid leaching. Int. J. Miner. Metall. Mater. 2016, 23, 491-500. [CrossRef] 